Four Zn( II )-MOFs as Highly Sensitive Chemical Sensor for the Rapid Detection

3 of Tetracycline, o-Nitro Phenol, $\mathrm{Cr}_{2} \mathrm{O}_{7}{ }^{2-} / \mathrm{PO}_{4}{ }^{3-}, \mathrm{Fe}^{3+} / \mathrm{Al}^{3+}$ in Water Environment

4 Wenbo Liu ${ }^{a}, N^{\prime}$ 'na $\mathrm{Li}^{a}{ }^{\text {, Xia Zhang }}{ }^{a}, \mathrm{Yu} \mathrm{Zhao}^{a}$, Ziao Zong ${ }^{b}$, Ruixue Wu ${ }^{a}$, Jiaping

$5 \quad$ Tong ${ }^{c, d}$, Caifeng $\mathrm{Bi}^{a}$, Feng Shao ${ }^{a, d *}$, Yuhua Fan ${ }^{a *}$

6

7

a. Key Laboratory of Marine Chemistry Theory and Technology, Ministry of Education, College of Chemistry and Chemical Engineering, Ocean University of China, Qingdao 266100, China

b. School of Laboratory Medicine, Youjiang Medical University for Nationalities, Baise 533000, China

c. Lab of Chemical Materials and Devices, Training Base of Army Logistics University of PLA, Chongqing 400041, China

d. State Key Laboratory of Physical Chemistry of Solid Surfaces, College of Chemistry and Chemical Engineering, Xiamen University, Xiamen 361005, China

*Corresponding author. E-mail address: fanyuhua301@163.com(Y.-H. Fan)

feng.shao@ouc.edu.cn (F. Shao) 20

(1)

2

3




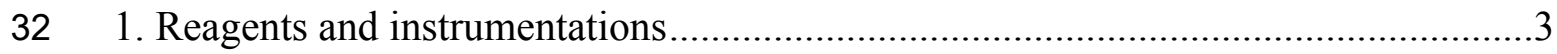

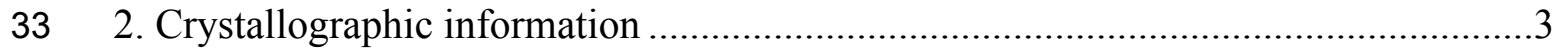

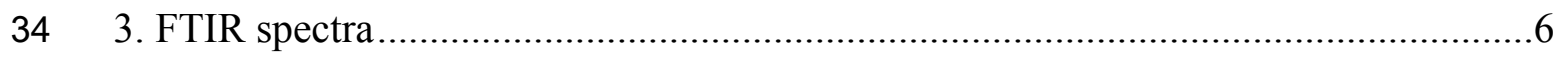

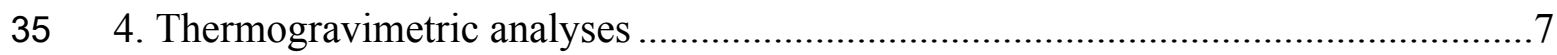

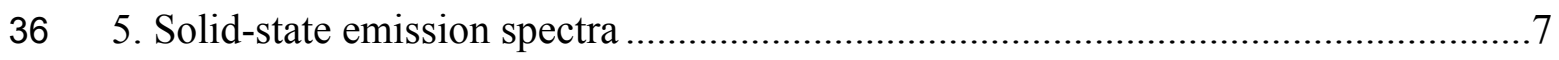

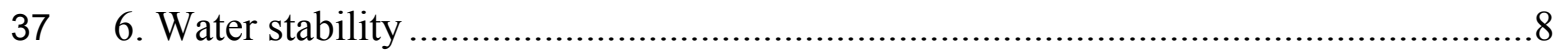

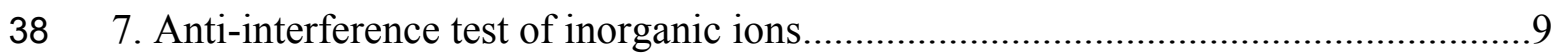

39 8. Luminescence intensity of the complexes in different concentrations of the detected

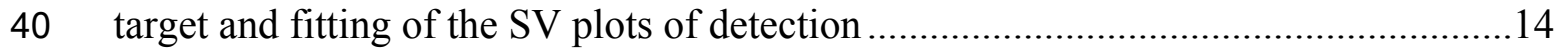

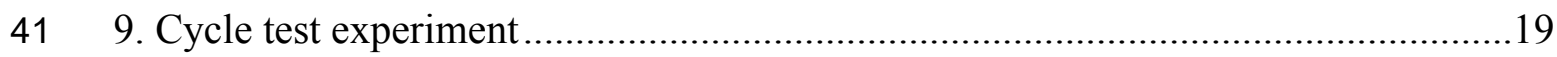

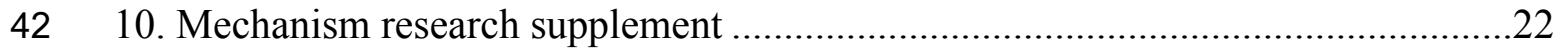

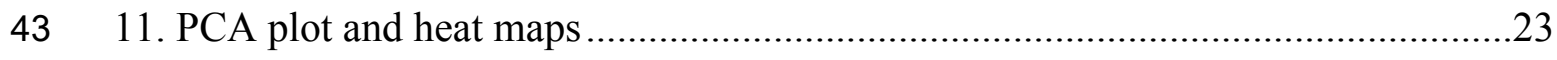

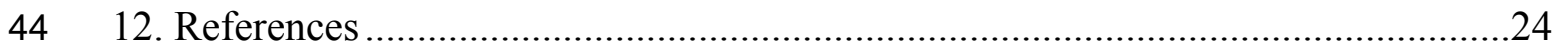

45

46 


\section{Reagents and instrumentations}

All starting materials were obtained commercially and were used without further purification unless otherwise stated. Water used in the experiment was deionized (DI) and twice distilled before being used as a cleaning agent.

The X-ray diffraction (XRD) patterns were performed on a D/max $2200 \mathrm{vpc}$ diffractometer (Rigaku Corporation, Japan) with the $\mathrm{Cu}-\mathrm{K \alpha}$ radiation. The infrared spectrum was recorded as $\mathrm{KBr}$ pellets on a Nicolet 170SX spectrometer in the 4000$400 \mathrm{~cm}^{-1}$ range. Thermogravimetric analysis (TGA) was performed on a Perkin-Elmer TGA-7 thermogravimetric analyzer under nitrogen conditions from room temperature to $900{ }^{\circ} \mathrm{C}$ with a heating rate of $10 \mathrm{~K} \cdot \mathrm{min}^{-1}$. The elemental analyses $(\mathrm{C}, \mathrm{H}, \mathrm{N})$ were measured on a 2400 model Perkin-Elmer analyzer. The powder X-ray diffraction (PXRD) patterns were collected from $5^{\circ}$ to $90^{\circ}$ with a step of $0.02^{\circ}$ and $0.5 \mathrm{~s}$ on an Ultima IV diffractometer with $\mathrm{Cu}-K \alpha$ radiation $(\lambda=1.5418 \AA)$ and a Lynxeye onedimensional detector. The 3D images of the MOF crystals were processed by the Diamond and TOPOS software to display the pores and structural topology of the samples ${ }^{1,2}$. The photoluminescence spectra were measured on a Hitachi F-4600 FL Spectrophotometer. ultraviolet-visible spectra (UV) were conducted on PerkinElmer Lambda 35 spectrometer.

\section{Crystallographic information}

The single-crystal X-ray diffraction data of 1-4 was collected on the Bruker Apex Smart CCDC diffractometer with graphite-monochromatized Mo-Ka radiation $(\lambda=$ $0.71073 \AA$ ) and $\omega-2 \Theta$ Scanning method. The structure analysis is done in the SHELXS97 software by the direct method; the non-hydrogen elements are identified by the Fourier synthesis method. The position and temperature parameters of the ions are refined to convergence using the full matrix least square method $\left(\mathrm{F}^{2}\right)$. 
Table S1. Summary of crystal data and structure refinement parameters for $\mathbf{2 , 3}$ and 4.

\begin{tabular}{|c|c|c|c|}
\hline & 2 & 3 & 4 \\
\hline CCDC no. & 2016808 & 1973610 & 1985510 \\
\hline Formula & $\mathrm{C}_{64} \mathrm{H}_{46} \mathrm{~N}_{10} \mathrm{O}_{21} \mathrm{Zn}_{4}$ & $\mathrm{C}_{26} \mathrm{H}_{19} \mathrm{~N}_{5} \mathrm{O}_{5} \mathrm{Zn}$ & $\mathrm{C}_{28} \mathrm{H}_{20} \mathrm{~N}_{4} \mathrm{O}_{4} \mathrm{Zn}$ \\
\hline$M r$ & 1552.59 & 546.83 & 541.85 \\
\hline$T(K)$ & 100 & 170 & 170 \\
\hline Crystal system & Monoclinic & Tetragonal & Monoclinic \\
\hline Space group & $C 2 / c$ & $I 4_{1} /$ acd & $P 2_{1} / n$ \\
\hline$a / \AA$ & $31.3570(9)$ & $17.9025(7)$ & $13.0513(8)$ \\
\hline$b / \AA$ & $11.5393(3)$ & $17.9025(7)$ & $11.3609(6)$ \\
\hline$c / \AA$ & $21.9176(6)$ & $63.370(3)$ & $15.2301(10)$ \\
\hline$\alpha\left(^{\circ}\right)$ & 90 & 90 & 90 \\
\hline$\beta\left(^{\circ}\right)$ & $132.5900(10)$ & 90 & $92.042(2)$ \\
\hline$\gamma\left({ }^{\circ}\right)$ & 90 & 90 & 90 \\
\hline$V\left(A^{3}\right)$ & $5838.6(3)$ & $20310.1(19)$ & $2256.8(2)$ \\
\hline$F(000)$ & 3152 & 8960 & 1112 \\
\hline$Z$ & 4 & 32 & 4 \\
\hline$\mu\left[\mathrm{mm}^{-1}\right]$ & 1.718 & 1.01 & 1.14 \\
\hline$R_{\text {int }}$ & 0.0520 & 0.057 & 0.062 \\
\hline $\begin{array}{l}\text { Calculated } \\
\text { density } / \mathrm{Mg} / \mathrm{m}^{3}\end{array}$ & 1.766 & 1.431 & 1.595 \\
\hline Gof & 1.058 & 1.117 & 1.186 \\
\hline Final $R$ indices & $R_{1}=0.0707$ & $R_{1}=0.0790$ & $R_{1}=0.0999$ \\
\hline$[I>2 \sigma(I)]$ & $w R_{2}=0.1793$ & $w R_{2}=0.1914$ & $w R_{2}=0.1223$ \\
\hline $\begin{array}{l}R \text { indices (all } \\
\text { data) }\end{array}$ & $\begin{array}{l}R_{1}=0.0950 \\
w R_{2}=0.1980\end{array}$ & $\begin{array}{l}R_{1}=0.0957 \\
w R_{2}=0.2001\end{array}$ & $\begin{array}{l}R_{1}=0.0304 \\
w R_{2}=0.2344\end{array}$ \\
\hline
\end{tabular}
$R_{1}=\Sigma\left\|F_{\mathrm{o}}|-| F_{\mathrm{c}}\right\| / \Sigma\left|F_{\mathrm{o}}\right|, w R_{2}=\left[\Sigma w\left(F_{\mathrm{o}}^{2}-F_{\mathrm{c}}^{2}\right)^{2}\right] /\left[\Sigma w\left(F_{\mathrm{o}}^{2}\right)^{2}\right]^{1 / 2}$. 
Table S2. Selected Bond lengths $[\AA]$ and angles $\left[{ }^{\circ}\right]$ for 2, 3 and 4.

\section{Complex 2}

\begin{tabular}{|c|c|c|c|}
\hline $\mathrm{Zn} 1-\mathrm{O} 1$ & $1.935(5)$ & $\mathrm{Zn} 2-\mathrm{O} 9^{\mathrm{iii}}$ & $2.264(8)$ \\
\hline $\mathrm{Zn} 1-\mathrm{O}^{\mathrm{i}}$ & $1.976(4)$ & $\mathrm{Zn} 2 \mathrm{~A}-\mathrm{O} 1$ & $1.884(4)$ \\
\hline $\mathrm{Zn} 1-\mathrm{N} 1^{\mathrm{ii}}$ & $2.015(5)$ & $\mathrm{Zn} 2 \mathrm{~A}-\mathrm{O} 2 \mathrm{~A}$ & $2.060(10)$ \\
\hline $\mathrm{Zn} 1-\mathrm{N} 4$ & $2.025(4)$ & $\mathrm{Zn} 2 \mathrm{~A}-\mathrm{O} 3$ & $1.919(6)$ \\
\hline $\mathrm{Zn} 2-\mathrm{O} 1$ & $1.790(5)$ & $\mathrm{Zn} 2 \mathrm{~A}-\mathrm{O} 9^{\mathrm{iii}}$ & $1.944(7)$ \\
\hline $\mathrm{Zn} 2-\mathrm{O} 2$ & $2.0248(17)$ & $\mathrm{Zn} 2 \mathrm{~A}-\mathrm{N} 5^{\mathrm{iv}}$ & $2.050(6)$ \\
\hline $\mathrm{Zn} 2-\mathrm{O} 3$ & $2.179(7)$ & & \\
\hline $\mathrm{O} 1-\mathrm{Zn} 1-\mathrm{O}^{\mathrm{i}}$ & 105.09 (19) & $\mathrm{O} 1-\mathrm{Zn} 1-\mathrm{N} 1^{\mathrm{ii}}$ & $112.8(2)$ \\
\hline $\mathrm{O} 1-\mathrm{Zn} 1-\mathrm{N} 4$ & 105.44 (19) & $\mathrm{O} 7 \mathrm{i}-\mathrm{Zn} 1-\mathrm{N} 1^{\mathrm{ii}}$ & $105.87(18)$ \\
\hline $\mathrm{O} 7 \mathrm{i}-\mathrm{Zn} 1-\mathrm{N} 4$ & $125.60(17)$ & $\mathrm{O} 1-\mathrm{Zn} 2-\mathrm{O} 2$ & $101.6(3)$ \\
\hline $\mathrm{N} 1 \mathrm{ii}-\mathrm{Zn} 1-\mathrm{N} 4$ & $102.18(18)$ & $\mathrm{O} 1-\mathrm{Zn} 2-\mathrm{O} 3$ & $108.2(2)$ \\
\hline $\mathrm{O} 1-\mathrm{Zn} 2-\mathrm{O} 9^{\mathrm{iii}}$ & $106.9(3)$ & $\mathrm{O} 2-\mathrm{Zn} 2-\mathrm{O} 3$ & $105.25(19)$ \\
\hline $\mathrm{O} 2-\mathrm{Zn} 2-\mathrm{O} 9^{\mathrm{iii}}$ & $141.1(3)$ & $\mathrm{O} 3-\mathrm{Zn} 2-\mathrm{O} 9^{\mathrm{iii}}$ & $90.5(3)$ \\
\hline $\mathrm{N} 5^{\mathrm{iv}}-\mathrm{Zn} 2 \mathrm{~A}-\mathrm{O} 2 \mathrm{~A}$ & $108.4(4)$ & $\mathrm{O} 3-\mathrm{Zn} 2 \mathrm{~A}-\mathrm{O} 2 \mathrm{~A}$ & $108.0(4)$ \\
\hline $\mathrm{O} 1-\mathrm{Zn} 2 \mathrm{~A}-\mathrm{O} 2 \mathrm{~A}$ & $101.8(4)$ & $\mathrm{O} 1-\mathrm{Zn} 2 \mathrm{~A}-\mathrm{O} 3$ & $115.9(2)$ \\
\hline $\mathrm{O} 1-\mathrm{Zn} 2 \mathrm{~A}-\mathrm{O} 9^{\mathrm{iii}}$ & $117.2(3)$ & $\mathrm{O} 1-\mathrm{Zn} 2 \mathrm{~A}-\mathrm{N} 5^{\mathrm{iv}}$ & $109.6(3)$ \\
\hline $\mathrm{O} 3-\mathrm{Zn} 2 \mathrm{~A}-\mathrm{N} 5^{\mathrm{iv}}$ & $114.2(4)$ & $\begin{array}{l}\mathrm{O} 9^{\mathrm{iii}-\mathrm{Zn} 2 \mathrm{~A}-} \\
\mathrm{O} 2 \mathrm{~A}\end{array}$ & $20.8(3)$ \\
\hline 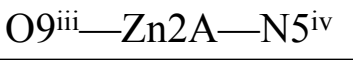 & $89.6(3)$ & & \\
\hline
\end{tabular}

\section{Complex 3}

$\mathrm{Zn} 1-\mathrm{O} 2$ $1.971(5)$

$\mathrm{Zn} 1-\mathrm{O} 4^{\mathrm{i}}$

$1.966(5)$

Zn1-N5

$\mathrm{Zn} 1-\mathrm{N} 1$

$2.000(5)$

$\mathrm{O} 2-\mathrm{Zn} 1-\mathrm{N} 5$

$111.3(2)$

$\mathrm{O} 2-\mathrm{Zn} 1-\mathrm{N} 1$

$103.6(2)$

$\mathrm{O} 4 \mathrm{i}-\mathrm{Zn} 1-\mathrm{O} 2$

$119.55(19)$

$\mathrm{O} 4 \mathrm{i}-\mathrm{Zn} 1-\mathrm{N} 5$

$99.4(2)$

$\mathrm{O} 4 \mathrm{i}-\mathrm{Zn} 1-\mathrm{N} 1$

$119.5(2)$

N1-Zn1-N5

$102.1(2)$

\section{Complex 4}

$\begin{array}{llll}\mathrm{Zn} 1-\mathrm{O} 3 & 1.972(6) & \mathrm{Zn} 1-\mathrm{O} 1 & 1.990(6) \\ \mathrm{Zn} 1-\mathrm{N} 1 & 2.026(6) & \mathrm{Zn} 1-\mathrm{N} 4 & 2.038(6) \\ \mathrm{O} 3-\mathrm{Zn} 1-\mathrm{N} 1 & 120.9(3) & \mathrm{O} 3-\mathrm{Zn} 1-\mathrm{O} 1 & 110.8(3) \\ \mathrm{O} 3-\mathrm{Zn} 1-\mathrm{N} 4{ }^{\mathrm{i}} & 104.0(3) & \mathrm{N} 1-\mathrm{Zn} 1-\mathrm{N} 4^{\mathrm{i}} & 113.5(3) \\ \mathrm{O} 1-\mathrm{Zn} 1-\mathrm{N} 1 & 107.0(3) & \mathrm{O} 1-\mathrm{Zn} 1-\mathrm{N} 4{ }^{\mathrm{i}} & 98.3(2)\end{array}$


a

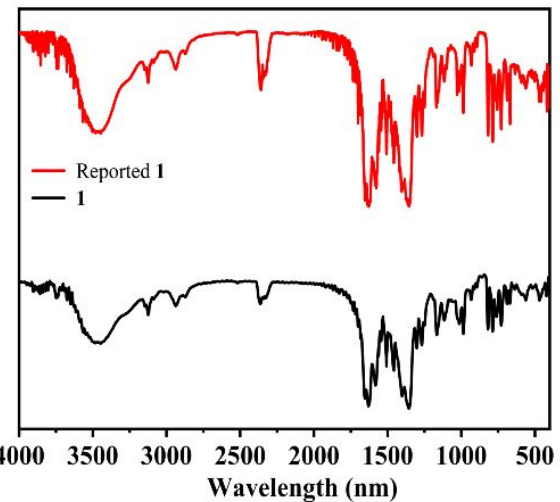

Wavelength (nm)

89
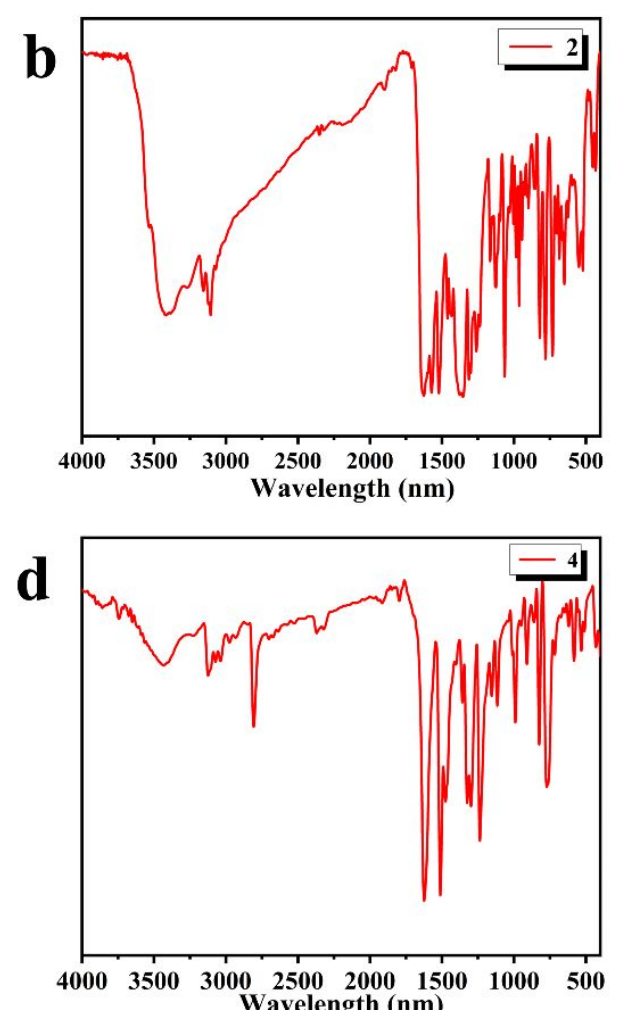

Wavelength (nm)

90 Figure S1. The FTIR spectra of $\mathbf{1 - 4}$. 

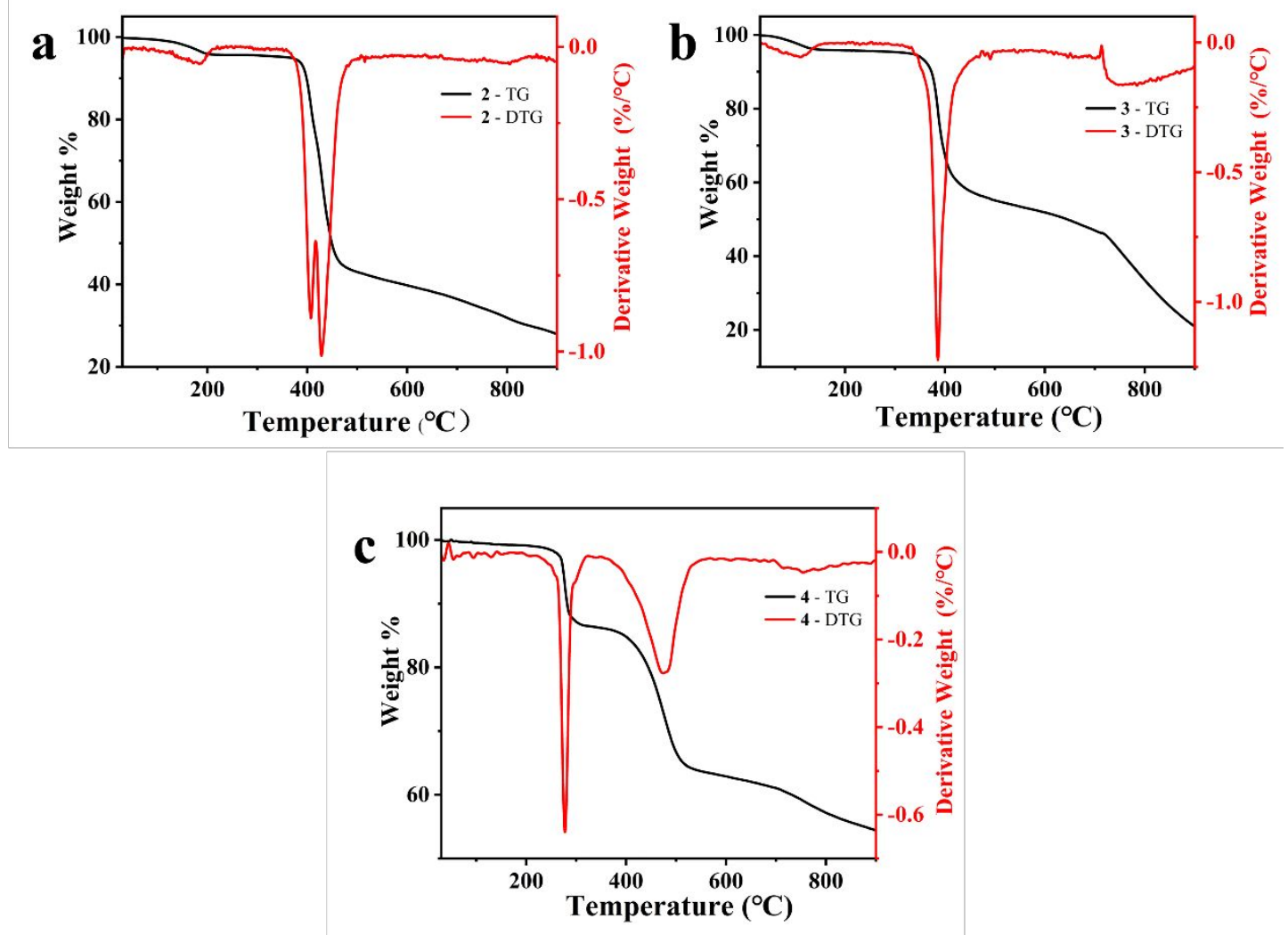

93 Figure S2. Thermogravimetric curve of $\mathbf{2}-\mathbf{4}$.

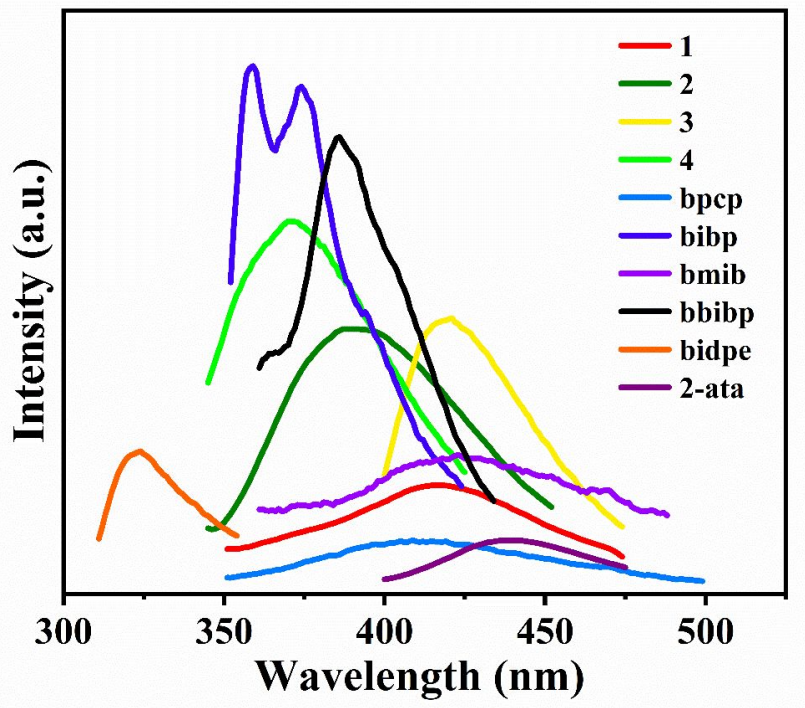

Figure S3. The solid state fluorescence of 1-4 and organic ligands. 

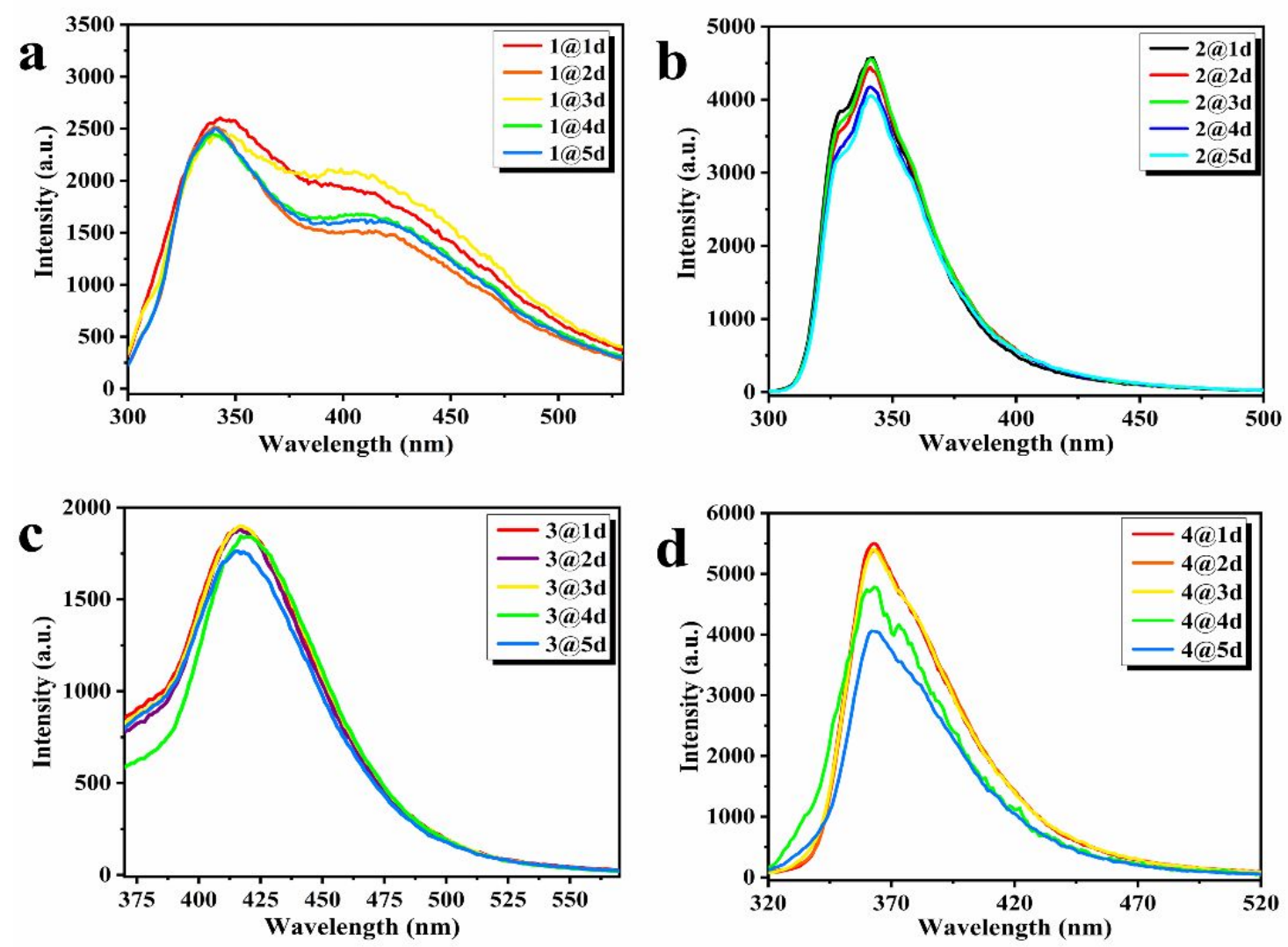

98

99 Figure S4. The fluorescence intensity of 1-4 in different days. 

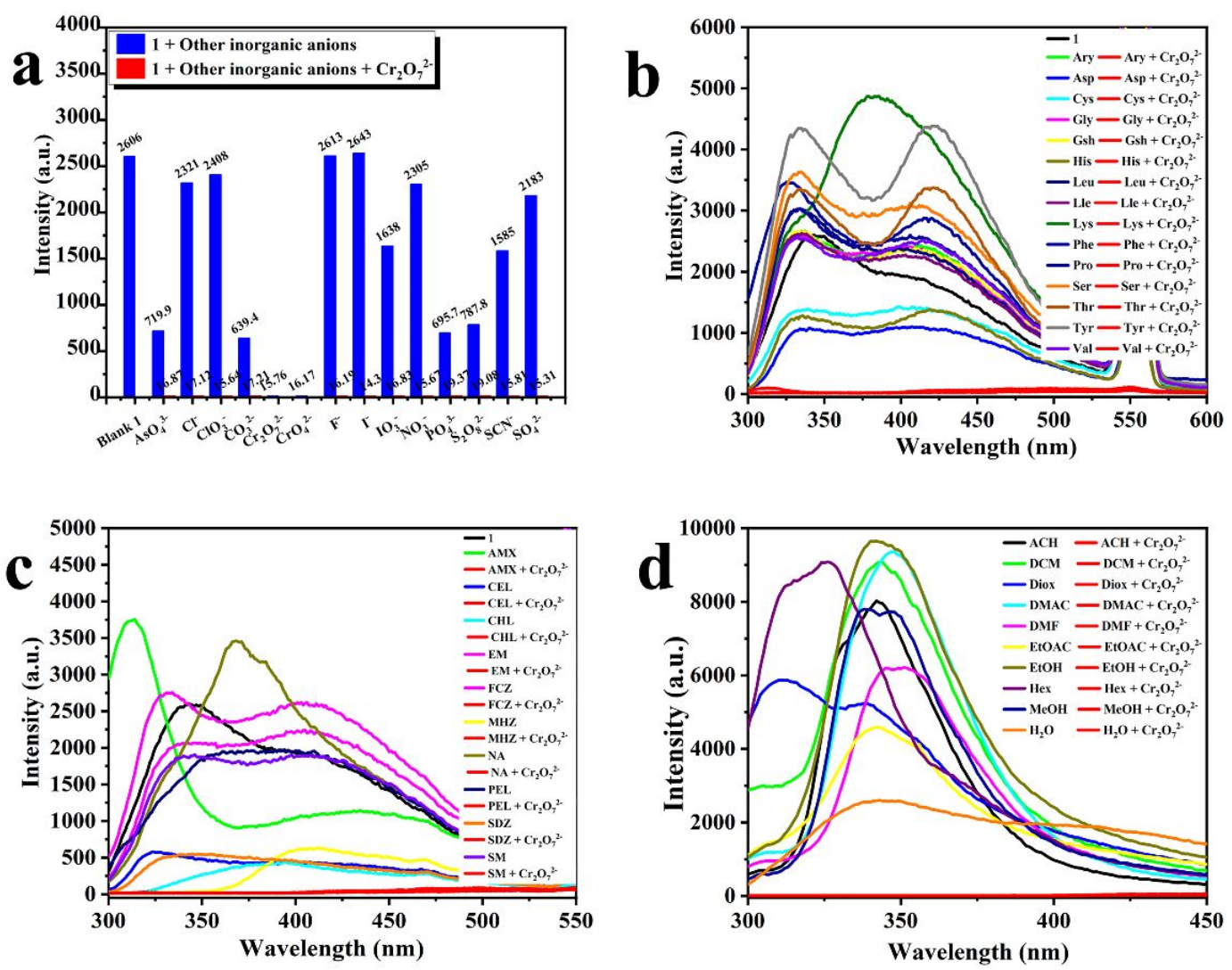

102 Figure S5. Fluorescence intensity response of (a) $\mathbf{1}$ in the presence of $\mathrm{Cr}_{2} \mathrm{O}_{7}{ }^{2-}$ and other 103 anions, (b) $\mathbf{1}$ in the presence of $\mathrm{Cr}_{2} \mathrm{O}_{7}{ }^{2-}$ and other amino acids, (c) $\mathbf{1}$ in the presence of $104 \mathrm{Cr}_{2} \mathrm{O}_{7}^{2-}$ and other antibiotics, (d) 1 in various organic solvents and after adding $\mathrm{Cr}_{2} \mathrm{O}_{7}{ }^{2-}$ 105 in organic solvents. 

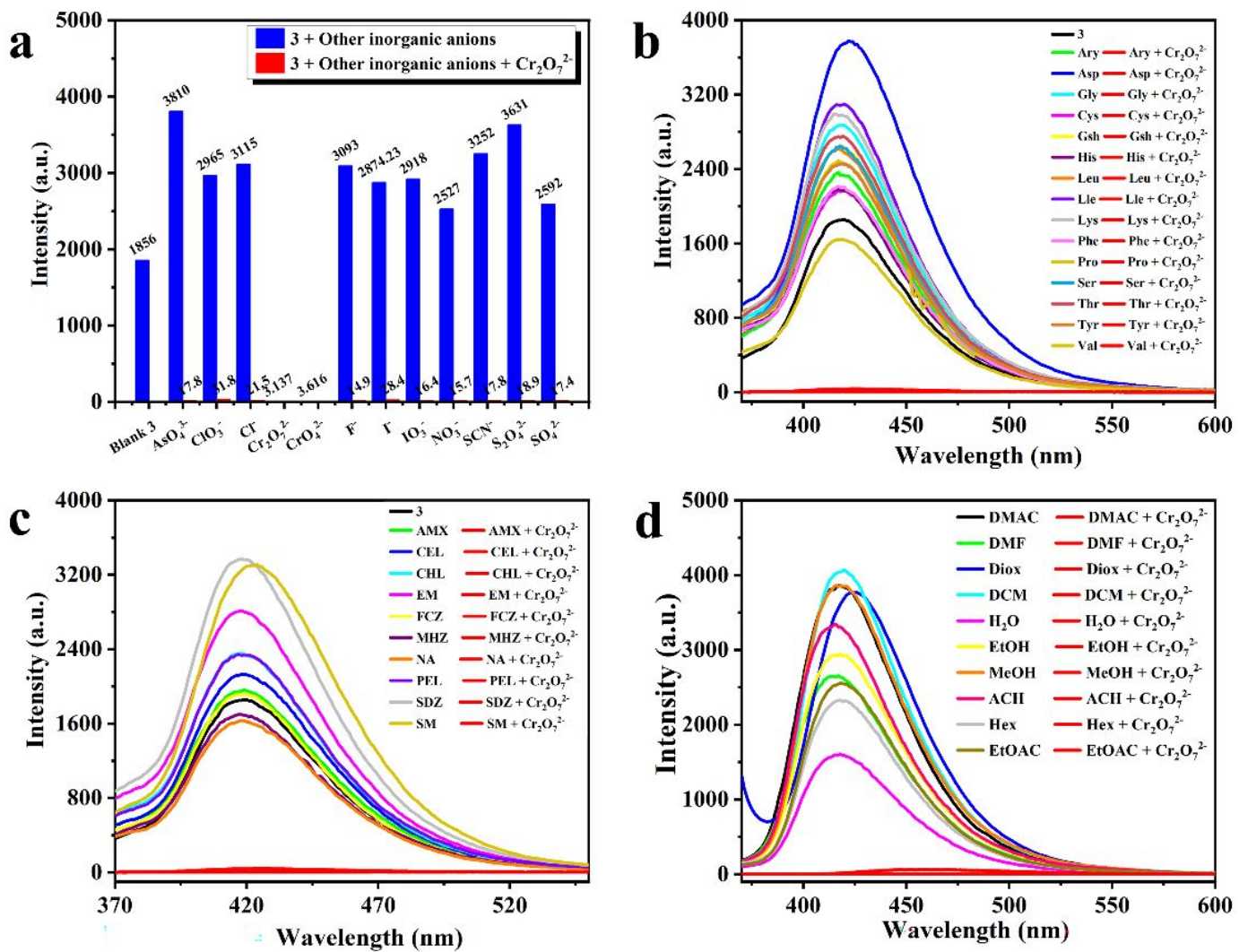

108 Figure S6. Fluorescence intensity response of (a) 3 in the presence of $\mathrm{Cr}_{2} \mathrm{O}_{7}{ }^{2-}$ and other 109 anions, (b) 3 in the presence of $\mathrm{Cr}_{2} \mathrm{O}_{7}{ }^{2-}$ and other amino acids, (c) 3 in the presence of $110 \mathrm{Cr}_{2} \mathrm{O}_{7}{ }^{2-}$ and other antibiotics, (d) 3 in various organic solvents and after adding $\mathrm{Cr}_{2} \mathrm{O}_{7}{ }^{2-}$ 111 in organic solvents. 

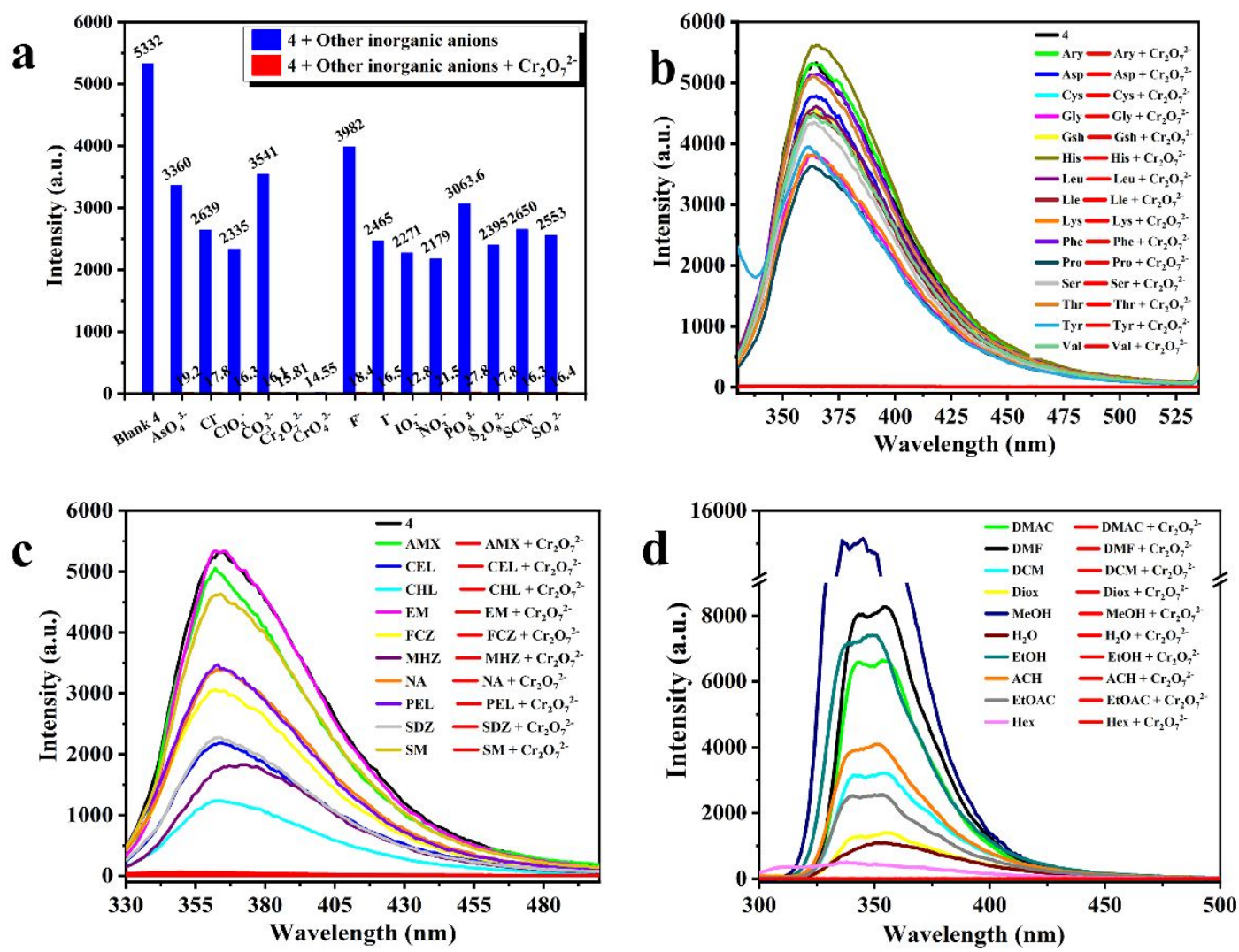

Figure S7. Fluorescence intensity response of (a) 4 in the presence of $\mathrm{Cr}_{2} \mathrm{O}_{7}{ }^{2-}$ and other anions, (b) 4 in the presence of $\mathrm{Cr}_{2} \mathrm{O}_{7}{ }^{2-}$ and other amino acids, (c) 4 in the presence of $\mathrm{Cr}_{2} \mathrm{O}_{7}{ }^{2-}$ and other antibiotics, (d) 4 in various organic solvents and after adding $\mathrm{Cr}_{2} \mathrm{O}_{7}{ }^{2-}$ in organic solvents. 

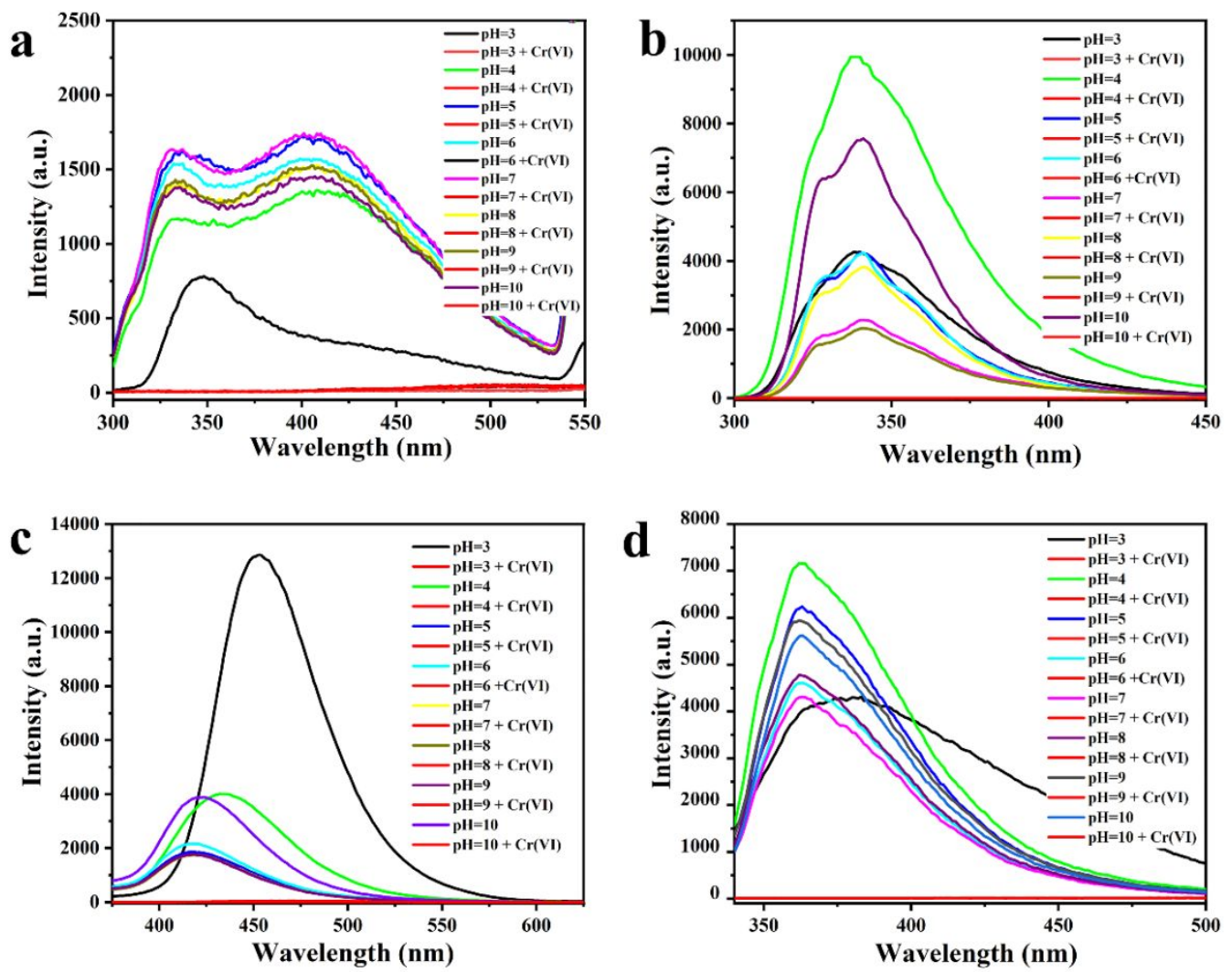

Figure S8. Fluorescence intensity response of (a) 1, (b) 2, (c) 3 and (d) 4 after adding $121 \mathrm{Cr}_{2} \mathrm{O}_{7}{ }^{2-}$ at different $\mathrm{pH}$. 

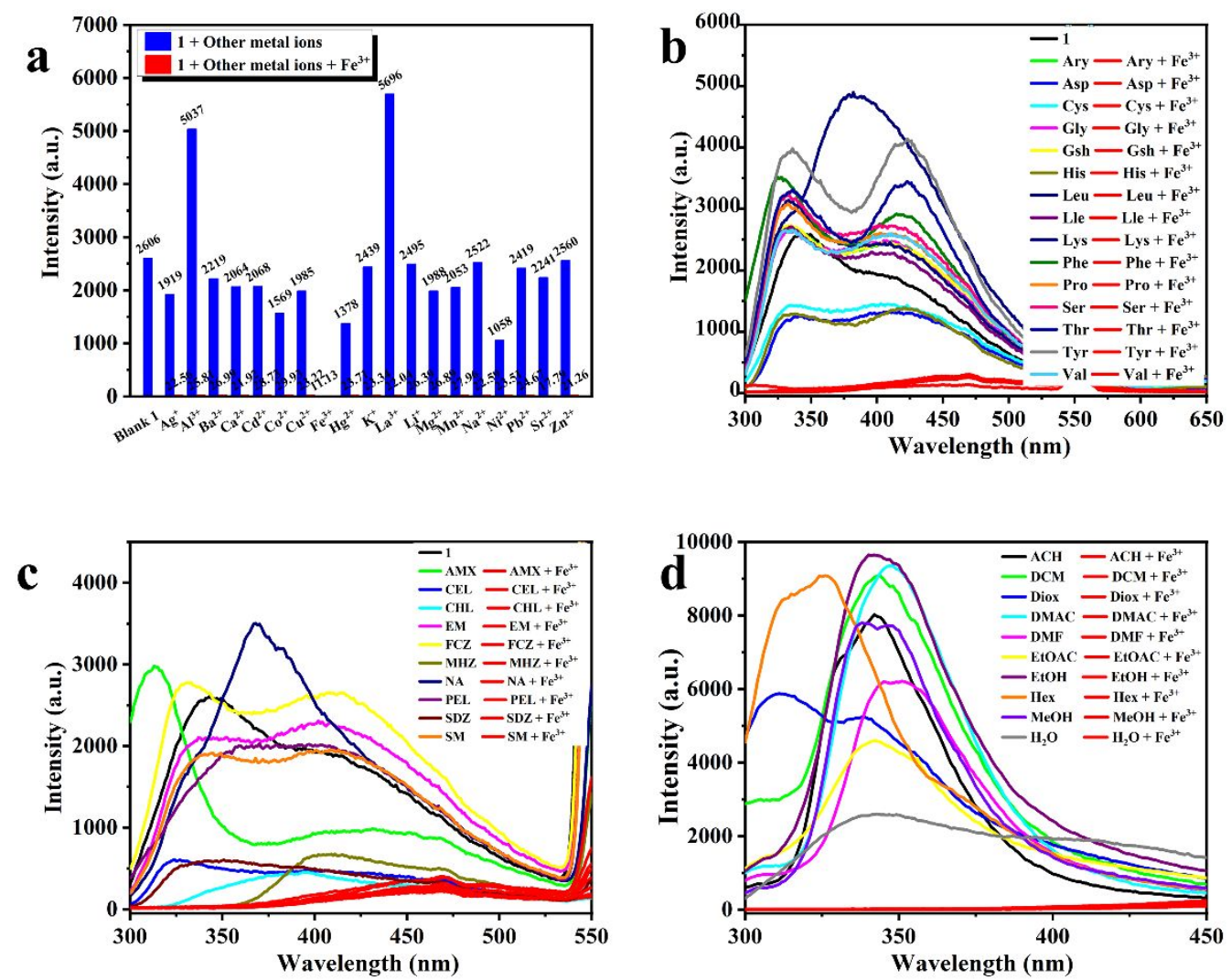

124 Figure S9. Fluorescence intensity response of (a) $\mathbf{1}$ in the presence of $\mathrm{Fe}^{3+}$ and other 125 anions, (b) 1 in the presence of $\mathrm{Fe}^{3+}$ and other amino acids, (c) 1 in the presence of $\mathrm{Fe}^{3+}$ 126 and other antibiotics, (d) $\mathbf{1}$ in various organic solvents and after adding $\mathrm{Fe}^{3+}$ in organic 127 solvents. 

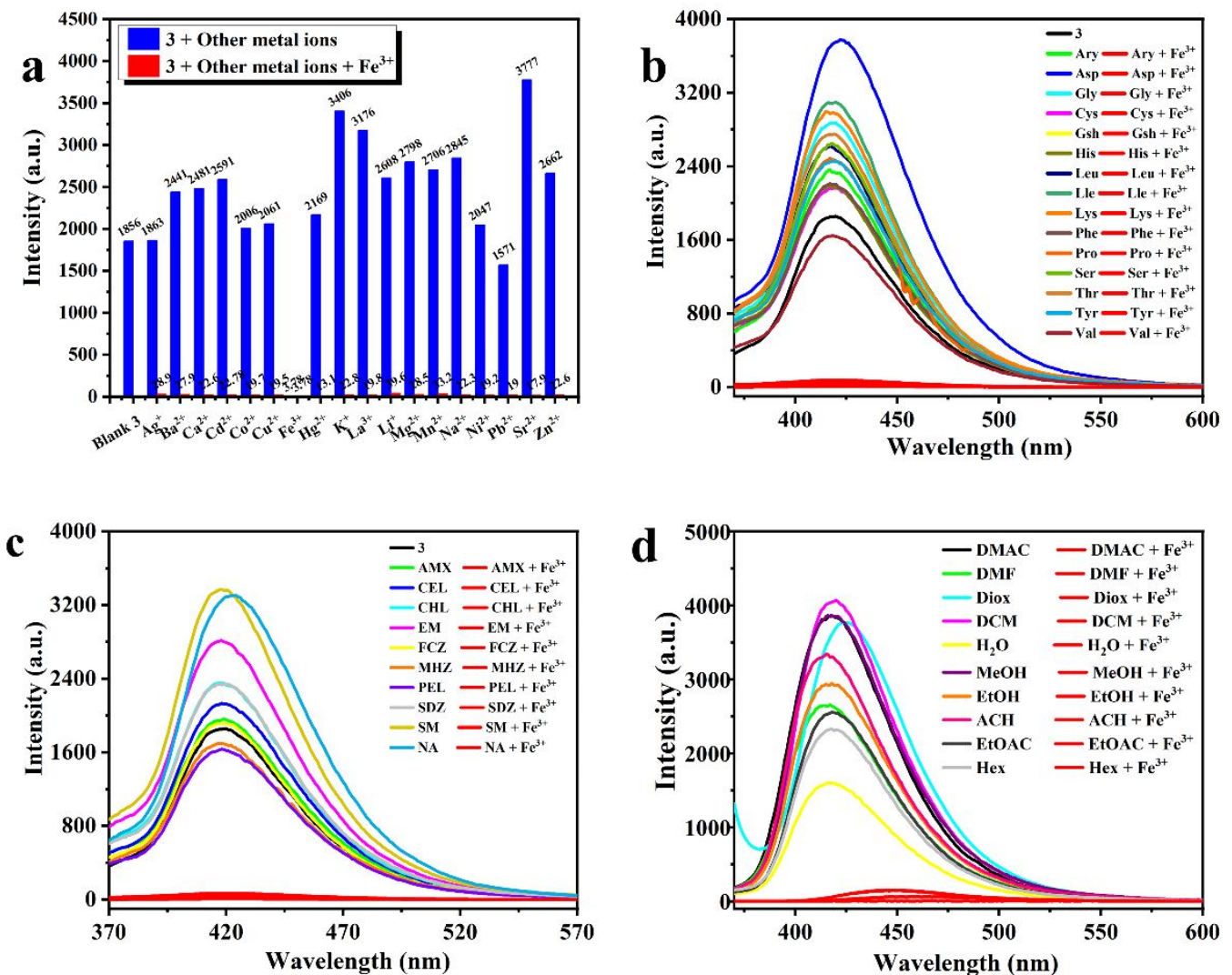

130 Figure S10. Fluorescence intensity response of (a) 3 in the presence of $\mathrm{Fe}^{3+}$ and other 131 anions, (b) 3 in the presence of $\mathrm{Fe}^{3+}$ and other amino acids, (c) 3 in the presence of $\mathrm{Fe}^{3+}$ 132 and other antibiotics, (d) 3 in various organic solvents and after adding $\mathrm{Fe}^{3+}$ in organic solvents. 

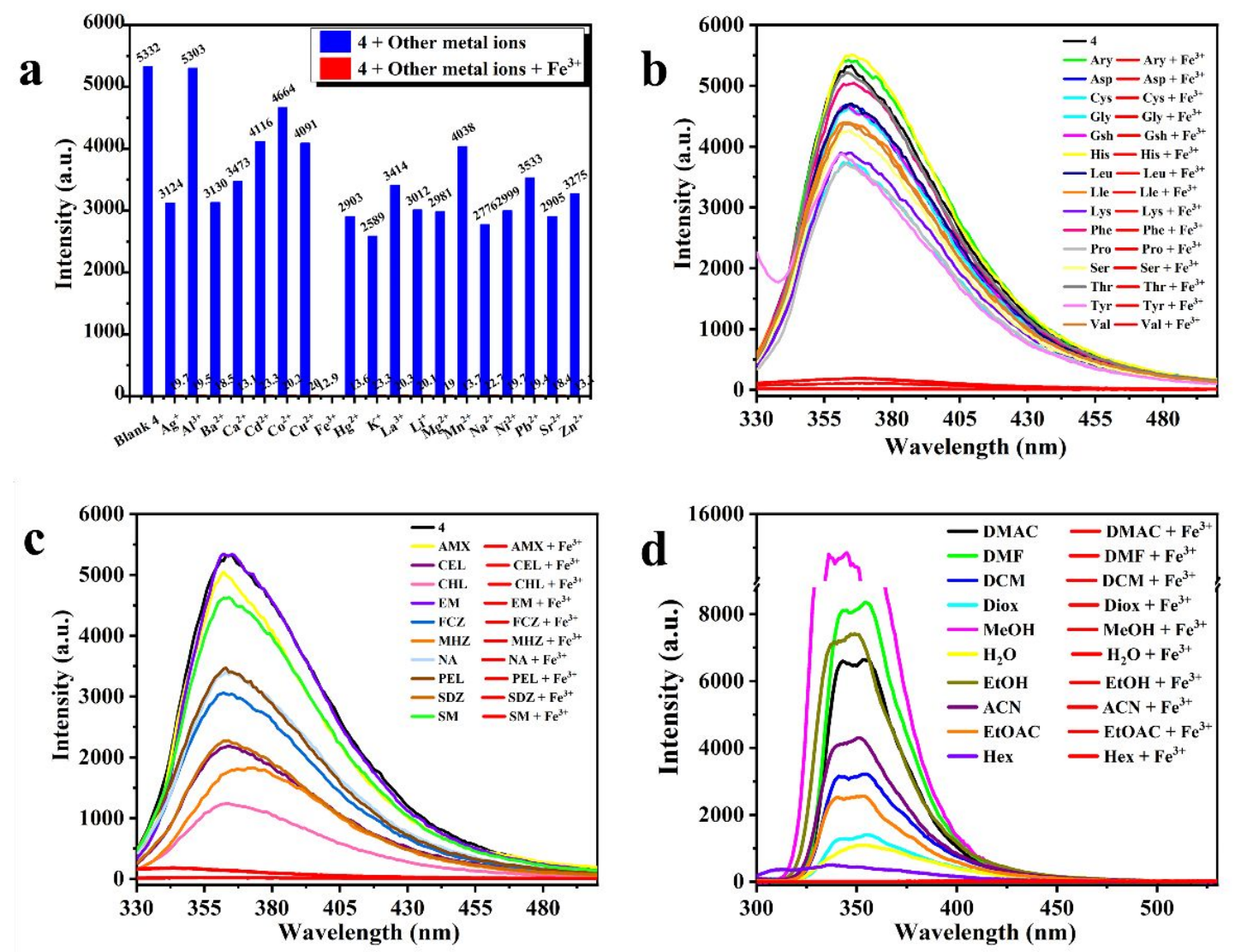

136 Figure S11. Fluorescence intensity response of (a) 4 in the presence of $\mathrm{Fe}^{3+}$ and other 137 anions, (b) 4 in the presence of $\mathrm{Fe}^{3+}$ and other amino acids, (c) 4 in the presence of $\mathrm{Fe}^{3+}$ 138 and other antibiotics, (d) 4 in various organic solvents and after adding $\mathrm{Fe}^{3+}$ in organic 139 solvents. 

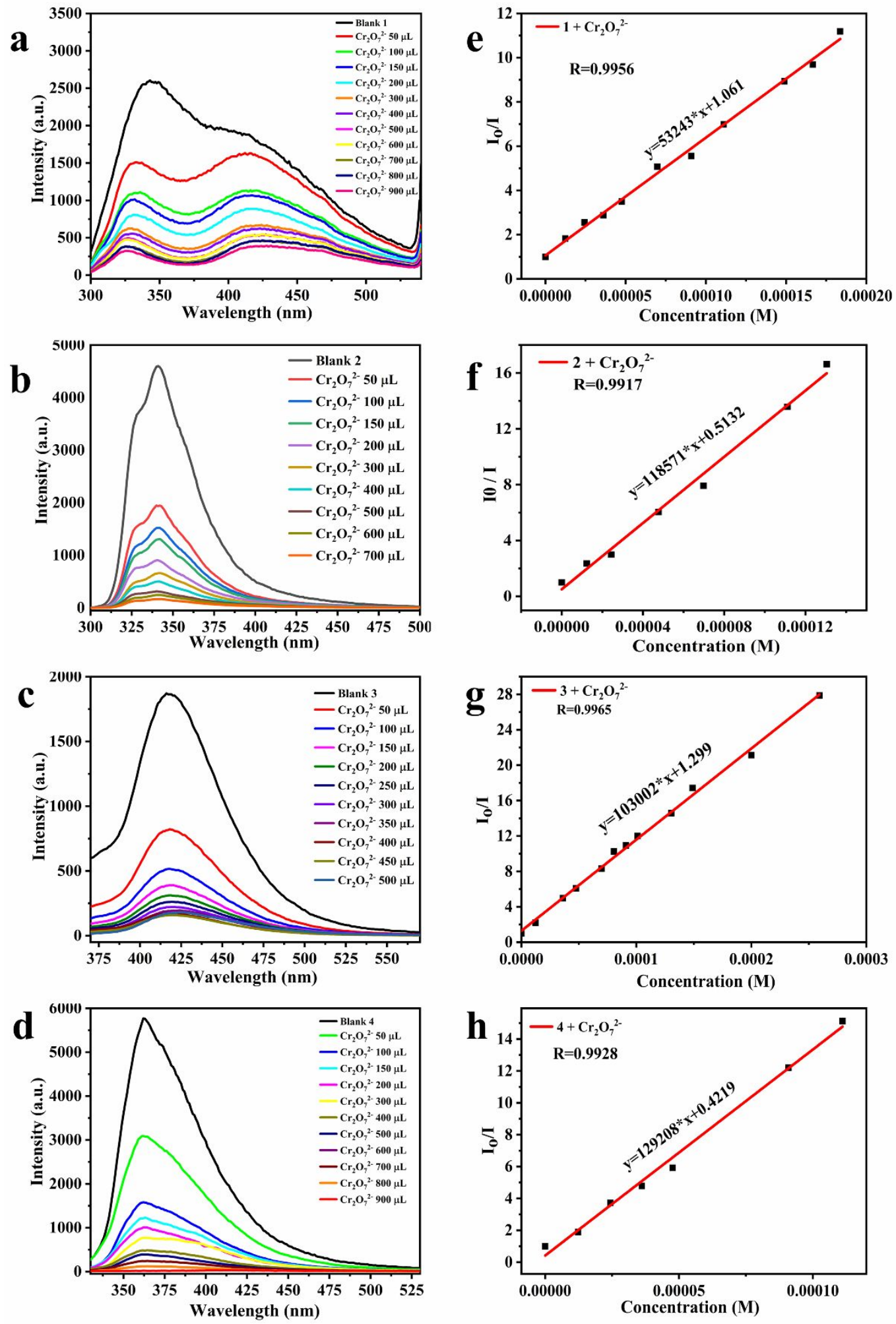

Figure S12. (a-d) The fluorescence spectra of 1-4 with different volumes of $\mathrm{Cr}_{2} \mathrm{O}_{7}{ }^{2-}$. 

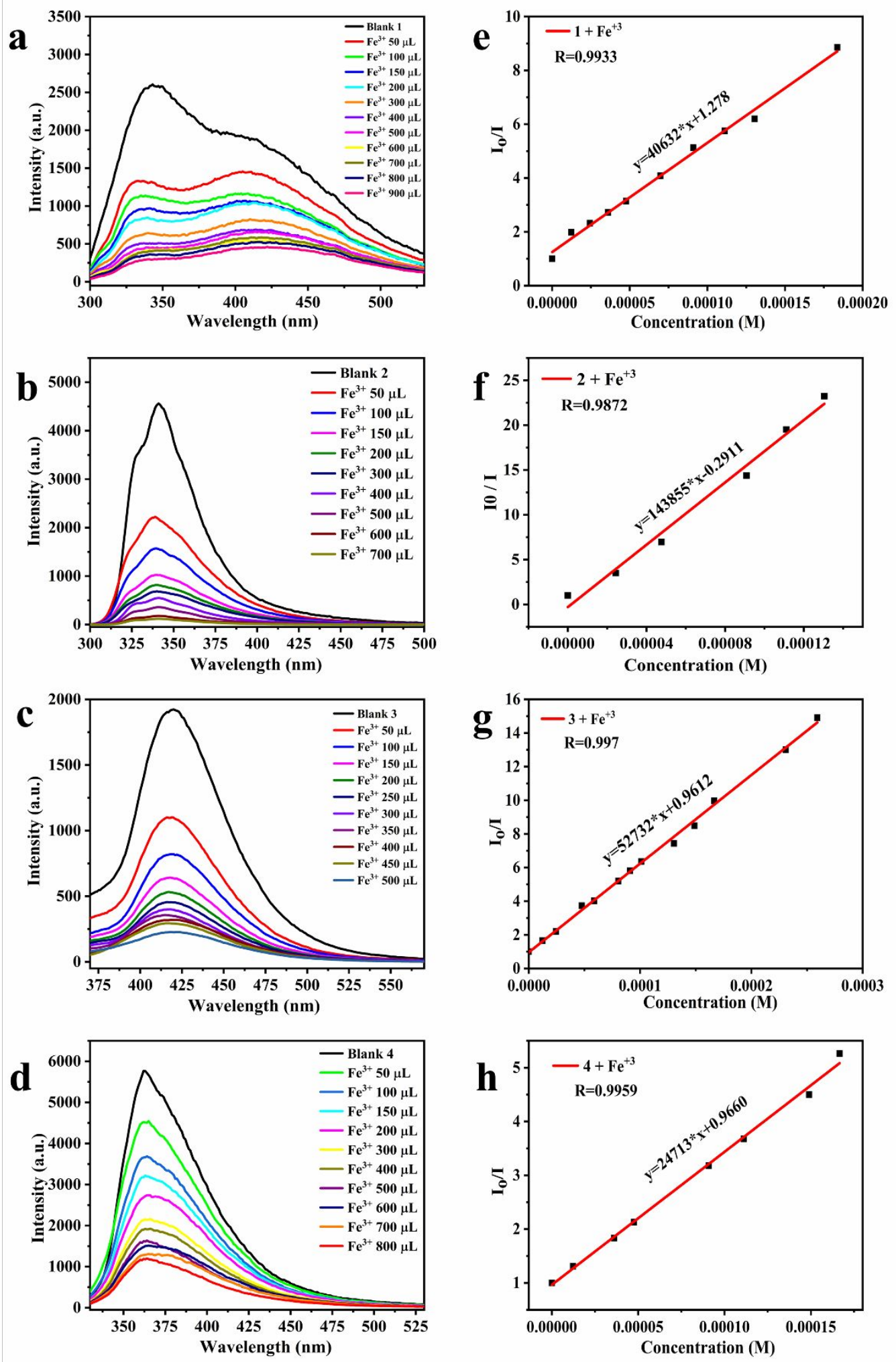

147 Figure S13. (a-d)The fluorescence spectra of 1-4 with different volumes of $\mathrm{Fe}^{3+}$. (e-

h) The fitting the $\mathrm{SV}$ equation of $\mathbf{1}-\mathbf{4}$ to $\mathrm{Fe}^{3+}$. 

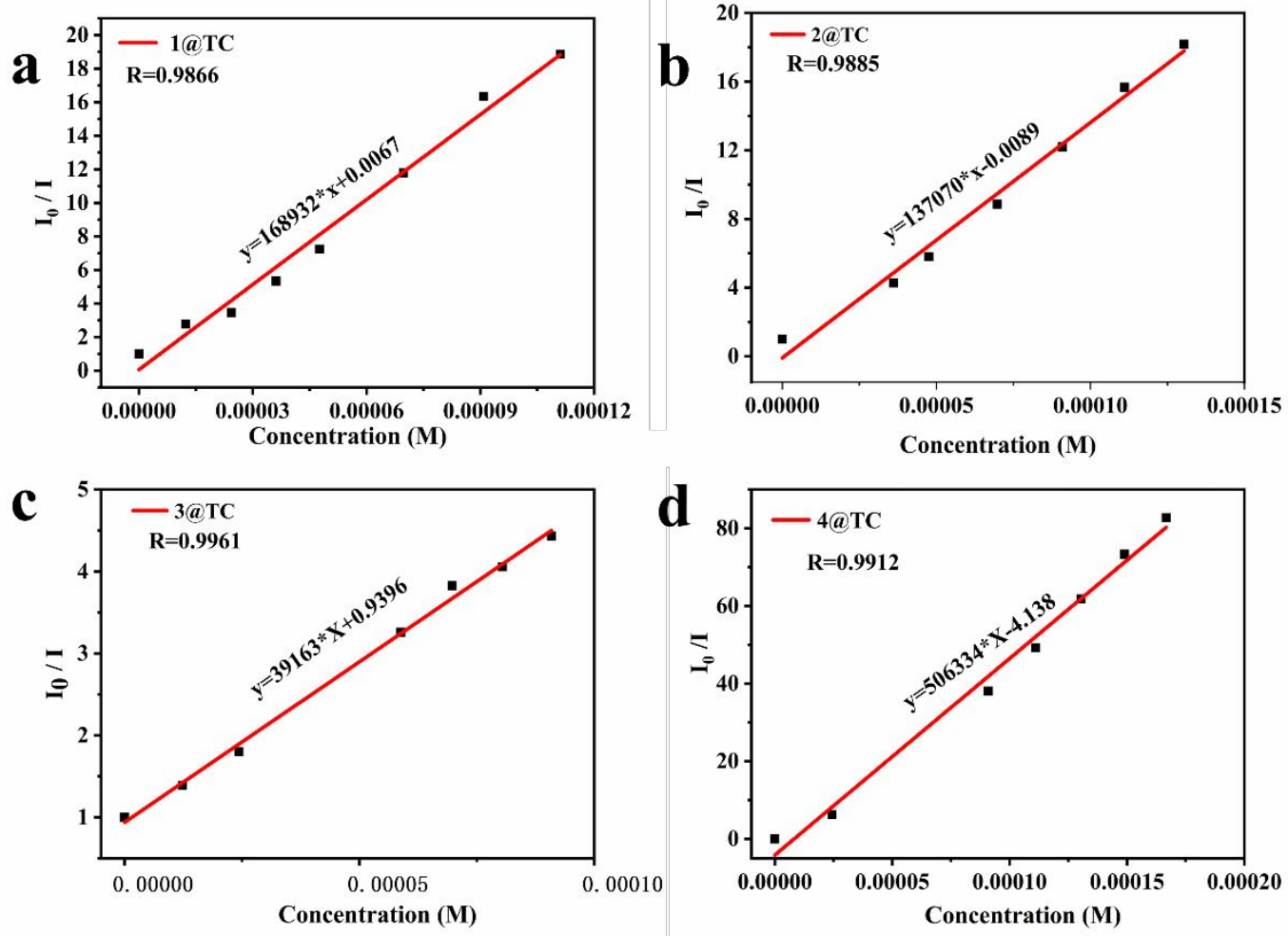

150 Figure S14. (a-d) The fitting the SV equation of $1-4$ to TC.
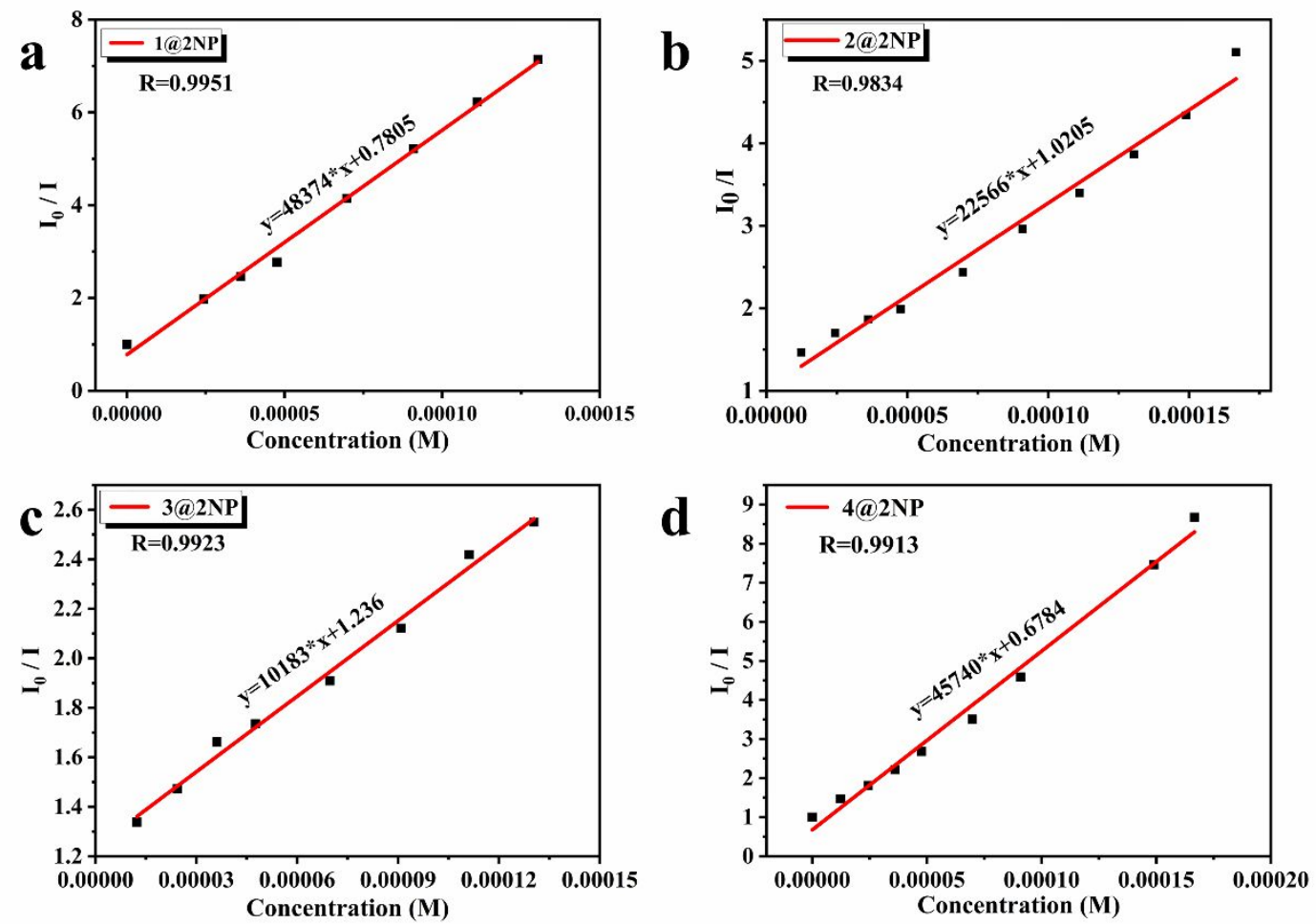

153 Figure S15. (a-d) The fitting the SV equation of 1-4 to 2NP. 


\section{a}

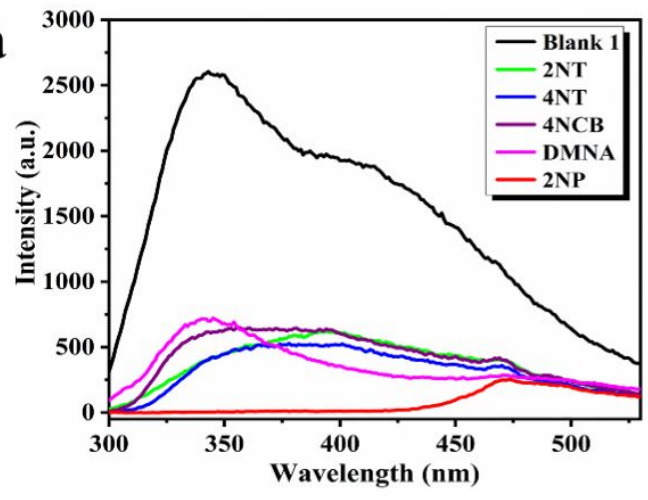

c

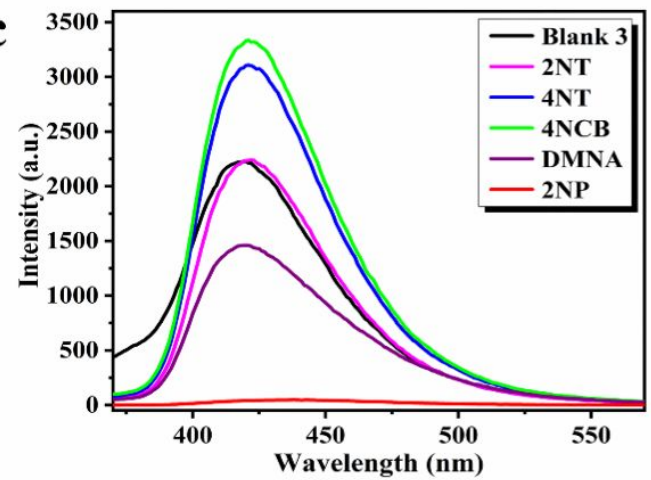

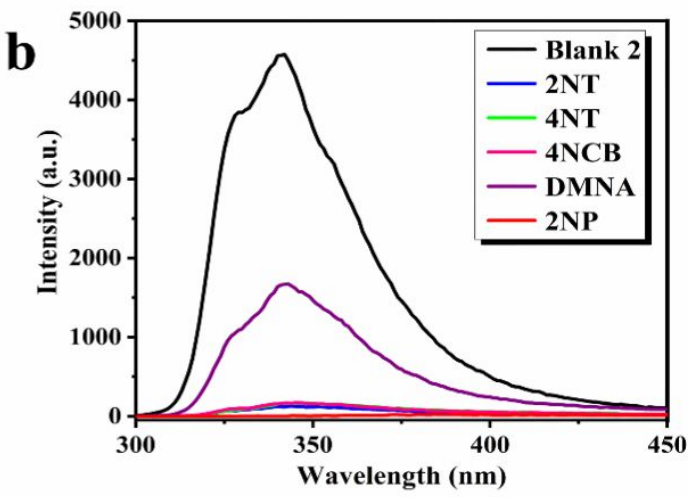

d

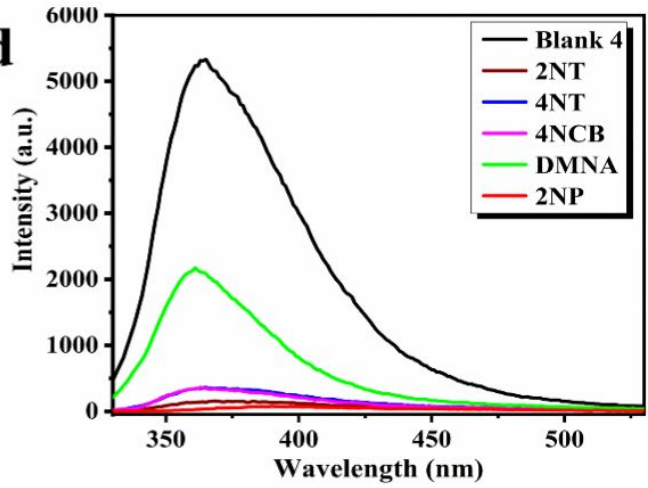

155 Figure S16. Fluorescence intensity response of five NACs to complexes $\mathbf{1 - 4}$.

157 Table S3. Comparison of photoluminescence properties of $\mathrm{Cr}_{2} \mathrm{O}_{7}^{2-}, \mathrm{Fe}^{3+}$, TC and 2NP 158 detected by $\mathbf{1}-\mathbf{4}$.

\begin{tabular}{cccc}
\hline Target & Sample & $\mathrm{K}_{\mathrm{SV}}\left(\mathrm{M}^{-1}\right)$ & LOD $(\mu \mathrm{M})$ \\
\hline $\mathrm{Cr}_{2} \mathrm{O}_{7}^{2-}$ & Complex $\mathbf{1}$ & 53243 & 0.71 \\
$\mathrm{Cr}_{2} \mathrm{O}_{7}^{2-}$ & Complex 2 & 118571 & 0.25 \\
$\mathrm{Cr}_{2} \mathrm{O}_{7}^{2-}$ & Complex 3 & 103002 & 0.29 \\
$\mathrm{Cr}_{2} \mathrm{O}_{7}^{2-}$ & Complex 4 & 129208 & 0.26 \\
$\mathrm{Fe}^{3+}$ & Complex $\mathbf{1}$ & 40632 & 1.43 \\
$\mathrm{Fe}^{3+}$ & Complex 2 & 143855 & 0.21 \\
$\mathrm{Fe}^{3+}$ & Complex 3 & 52732 & 0.57 \\
$\mathrm{Fe}^{3+}$ & Complex 4 & 24713 & 1.36 \\
$\mathrm{TC}$ & Complex $\mathbf{1}$ & 168932 & 0.22 \\
$\mathrm{TC}$ & Complex 2 & 137070 & 0.23 \\
$\mathrm{TC}$ & Complex 3 & 39163 & 0.78 \\
$\mathrm{TC}$ & Complex 4 & 506334 & 0.06 \\
$2 \mathrm{NP}$ & Complex $\mathbf{1}$ & 48374 & 0.79 \\
$2 \mathrm{NP}$ & Complex 2 & 22566 & 1.34 \\
$2 \mathrm{NP}$ & Complex 3 & 10183 & 2.98 \\
\hline
\end{tabular}




\section{NP}

Complex 4

45740

0.73

Table S4. Comparison of photoluminescence properties of $\mathrm{Al}^{3+}$ and $\mathrm{PO}_{4}{ }^{3-}$ detected by

160 Complex 3.

\begin{tabular}{cccc}
\hline Target & Sample & $\mathrm{K}_{\mathrm{SV}}\left(\mathrm{M}^{-1}\right)$ & LOD $(\mu \mathrm{M})$ \\
\hline $\mathrm{Al}^{3+}$ & Complex $\mathbf{3}$ & 12300 & 3.17 \\
$\mathrm{PO}_{4}{ }^{3-}$ & Complex $\mathbf{3}$ & 6010 & 6.49 \\
\hline
\end{tabular}

Table S5. The detection limit of recently reported harmful substance detection based 163 on MOFs system.

\begin{tabular}{|c|c|c|c|c|}
\hline Detector & Target & Mode & $\operatorname{LOD}(\mu \mathrm{M})$ & Ref. \\
\hline UiO-66- $\mathrm{NH}_{2}-\mathrm{SA}$ & $\mathrm{Al}^{3+}$ & fluorometric & 6.89 & 3 \\
\hline$\left[\mathrm{Co}_{2}(\mathrm{dmimpym})(\mathrm{nda})_{2}\right]_{\mathrm{n}}$ & $\mathrm{Al}^{3+}$ & Fluorescence enhancement & 0.7 & 4 \\
\hline$\left[\mathrm{Tb}(\mathrm{ppda})(\mathrm{ox})_{0.5}\left(\mathrm{H}_{2} \mathrm{O}\right)_{2}\right]_{\mathrm{n}}$ & $\mathrm{Al}^{3+}$ & Fluorescence enhancement & 5.66 & 5 \\
\hline JXUST-2 & $\mathrm{Al}^{3+}$ & Fluorescence enhancement & 0.10 & 6 \\
\hline 3 & $\mathrm{Al}^{3+}$ & Fluorescence enhancement & 3.17 & This work \\
\hline UiO-66-(Fe / Zr)-NH & $\mathrm{PO}_{4}^{3-}$ & Ratiometric fluorescent & 0.085 & 7 \\
\hline $\mathrm{C}_{38} \mathrm{H}_{22} \mathrm{Eu}_{2} \mathrm{~N}_{2} \mathrm{O}_{16}$ & $\mathrm{PO}_{4}^{3-}$ & Fluorescence quenching & 14.2 & 8 \\
\hline 3 & $\mathrm{PO}_{4}^{3-}$ & Fluorescence enhancement & 6.49 & This work \\
\hline $\mathrm{Zn}($ II $)-\mathrm{MOF}-1$ & $\mathrm{Fe}^{3+}$ & Fluorescence quenching & 5.51 & 9 \\
\hline BUT-14 & $\mathrm{Fe}^{3+}$ & Fluorescence quenching & 3.8 & 10 \\
\hline BUT-15 & $\mathrm{Fe}^{3+}$ & Fluorescence quenching & 0.3 & 10 \\
\hline JXUST-2 & $\mathrm{Fe}^{3+}$ & Fluorescence enhancement & 0.13 & 6 \\
\hline Tb-MOF & $\mathrm{Fe}^{3+}$ & Fluorescence quenching & 0.022 & 11 \\
\hline 1 & $\mathrm{Fe}^{3+}$ & Fluorescence quenching & 1.43 & This work \\
\hline 2 & $\mathrm{Fe}^{3+}$ & Fluorescence quenching & 0.21 & This work \\
\hline 3 & $\mathrm{Fe}^{3+}$ & Fluorescence quenching & 0.57 & This work \\
\hline 4 & $\mathrm{Fe}^{3+}$ & Fluorescence quenching & 1.36 & This work \\
\hline $\mathrm{Co}($ II )-MOF & $\mathrm{Cr}_{2} \mathrm{O}_{7}^{2-}$ & Fluorescence quenching & 0.099 & 12 \\
\hline $\mathrm{Mn}^{2+}: \mathrm{ZnS}$ QDs/ZIF-8 & $\mathrm{Cr}_{2} \mathrm{O}_{7}^{2-}$ & Fluorescence changes & 0.22 & 13 \\
\hline BUT-39 & $\mathrm{Cr}_{2} \mathrm{O}_{7}^{2-}$ & Fluorescence quenching & 1.5 & 14 \\
\hline $\begin{array}{l}{\left[\mathrm{Zn}_{2}(\mathrm{TPOM})\left(\mathrm{NH}_{2-}\right.\right.} \\
\left.\mathrm{BDC})_{2}\right] \cdot 4 \mathrm{H}_{2} \mathrm{O}\end{array}$ & $\mathrm{Cr}_{2} \mathrm{O}_{7}^{2-}$ & Fluorescence quenching & 3.9 & 15 \\
\hline 1 & $\mathrm{Cr}_{2} \mathrm{O}_{7}^{2-}$ & Fluorescence quenching & 0.71 & This work \\
\hline 2 & $\mathrm{Cr}_{2} \mathrm{O}_{7}^{2-}$ & Fluorescence quenching & 0.25 & This work \\
\hline 3 & $\mathrm{Cr}_{2} \mathrm{O}_{7}^{2-}$ & Fluorescence quenching & 0.29 & This work \\
\hline 4 & $\mathrm{Cr}_{2} \mathrm{O}_{7}^{2-}$ & Fluorescence quenching & 0.26 & This work \\
\hline PCN-128Y & $\mathrm{TC}$ & Fluorescence quenching & 0.03 & 16 \\
\hline
\end{tabular}




\begin{tabular}{lllll}
\hline NH2-MIL-53(Al) & TC & Fluorescence quenching & 0.026 & 17 \\
AuCuNCs @ ZIF-8 & TC & ratiometric fluorescent & 0.0048 & 18 \\
$\mathbf{1}$ & TC & Fluorescence quenching & 0.22 & This work \\
$\mathbf{2}$ & TC & Fluorescence quenching & 0.23 & This work \\
$\mathbf{3}$ & TC & Fluorescence quenching & 0.78 & This work \\
$\mathbf{4}$ & TC & Fluorescence quenching & 0.06 & This work \\
$\mathrm{Cd}(\mathrm{II})-\mathrm{MOF}-1$ & $4 \mathrm{NP}$ & Fluorescence quenching & 58 & 19 \\
$\left\{\left[\mathrm{Zn}_{3}(\mathrm{mtrb})_{3}(\mathrm{btc})_{2}\right] \cdot 3 \mathrm{H}_{2} \mathrm{O}\right\}_{\mathrm{n}}$ & $4 \mathrm{NP}$ & Fluorescence quenching & 2.56 & 20 \\
$\left\{\left[\mathrm{Zn} \mathrm{n}_{3}(\mathrm{mtrb})_{3}(\mathrm{btc})_{2}\right] \cdot 3 \mathrm{H}_{2} \mathrm{O}\right\}_{\mathrm{n}}$ & $2 \mathrm{NP}$ & Fluorescence quenching & 23.82 & 20 \\
$\mathbf{1}$ & $2 \mathrm{NP}$ & Fluorescence quenching & 0.79 & This work \\
$\mathbf{2}$ & $2 \mathrm{NP}$ & Fluorescence quenching & 1.34 & This work \\
$\mathbf{3}$ & $2 \mathrm{NP}$ & Fluorescence quenching & 2.98 & This work \\
$\mathbf{4}$ & $2 \mathrm{NP}$ & Fluorescence quenching & 0.73 & This work \\
\hline
\end{tabular}

\section{Cycle test experiment}
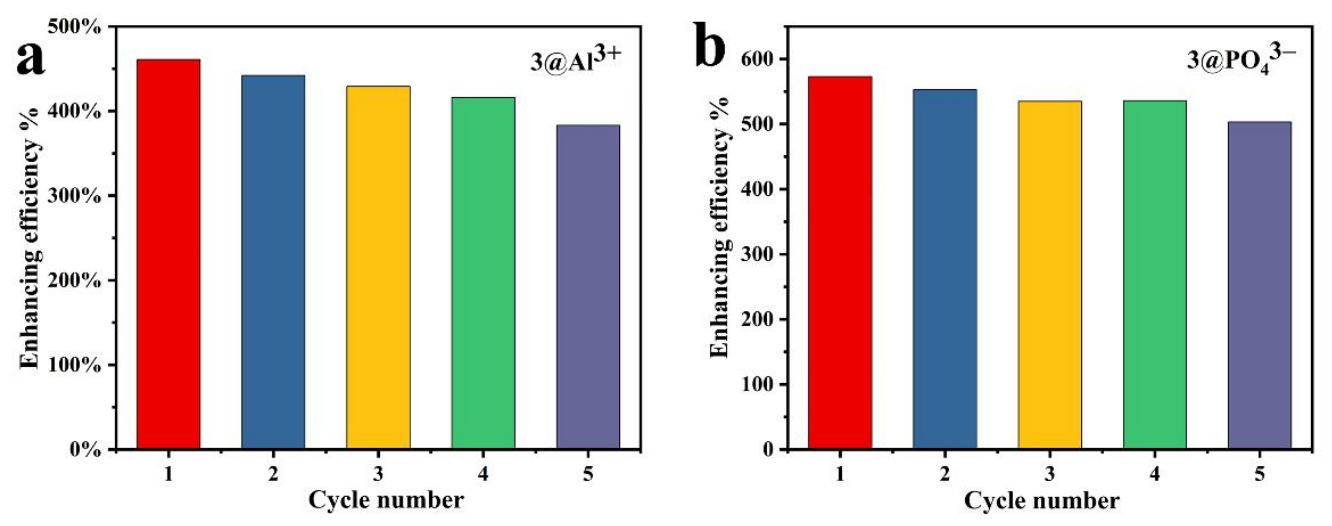

Figure S17. The fluorescence enhancement efficiency of 3 for $\mathrm{Al}^{3+}$ and $\mathrm{PO}_{4}{ }^{3-}$ in 5 cycles experiment. 

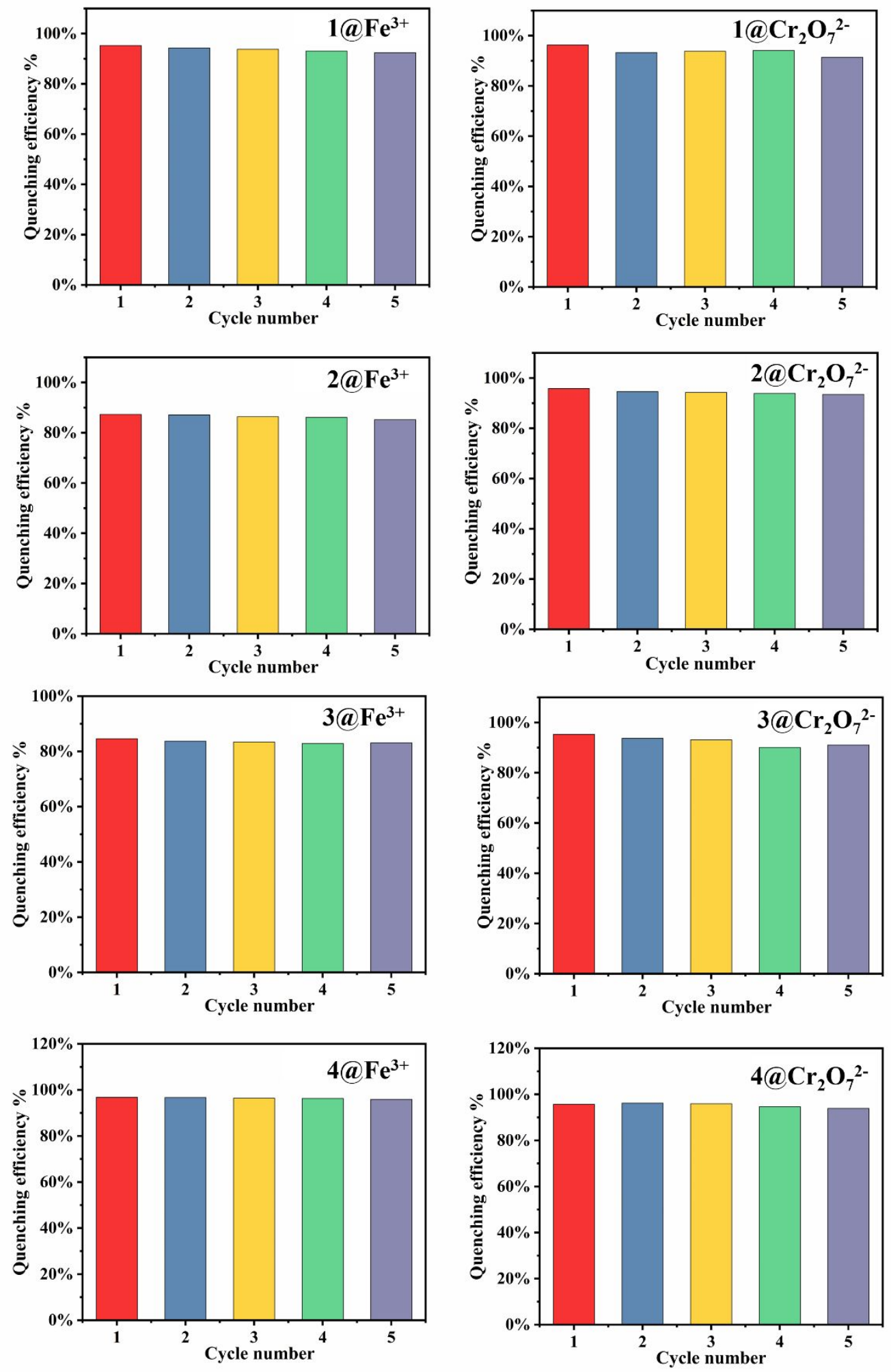

171 Figure S18. The fluorescence quenching efficiency of $\mathbf{1 - 4}$ for $\mathrm{Fe}^{3+}$ and $\mathrm{Cr}_{2} \mathrm{O}_{7}^{2-}$ in 5 172 cycles experiment. 

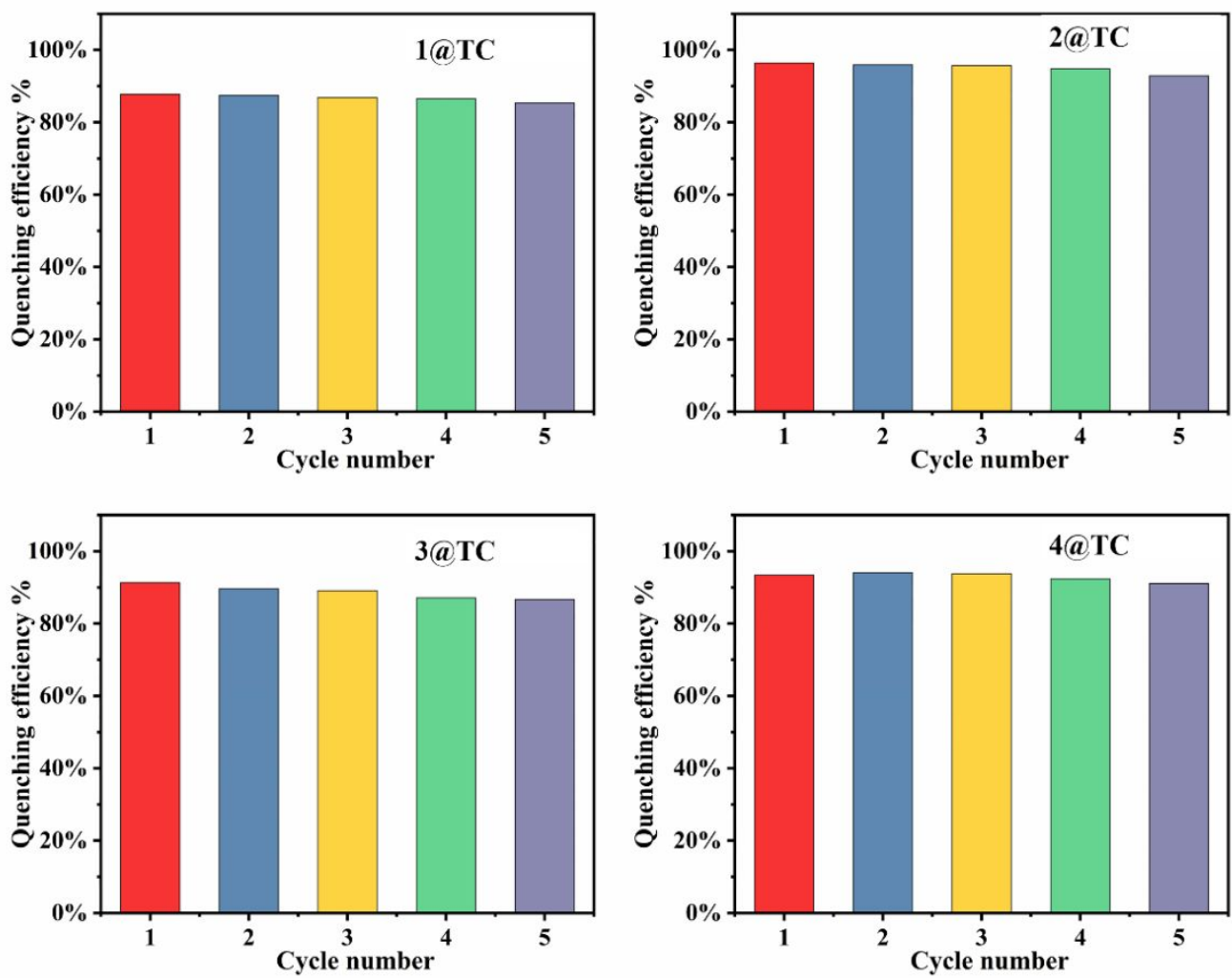

174 Figure S19. The fluorescence quenching efficiency of 1-4 for TC in 5 cycles 175 experiment.
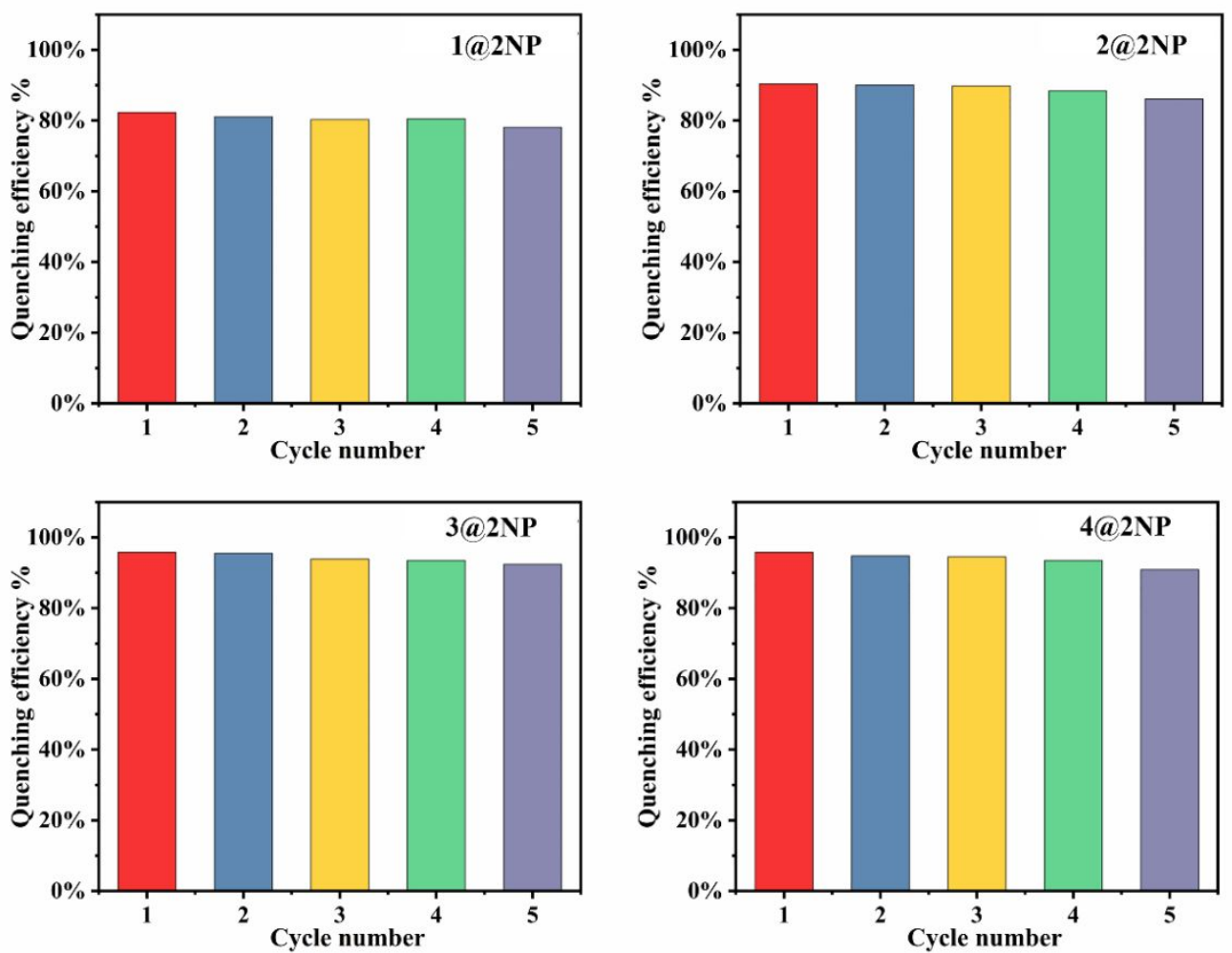

177 Figure S20. The fluorescence quenching efficiency of complexes 1-4 for $2 \mathrm{NP}$ in 5 
cycles experiment.

10. Mechanism research supplement

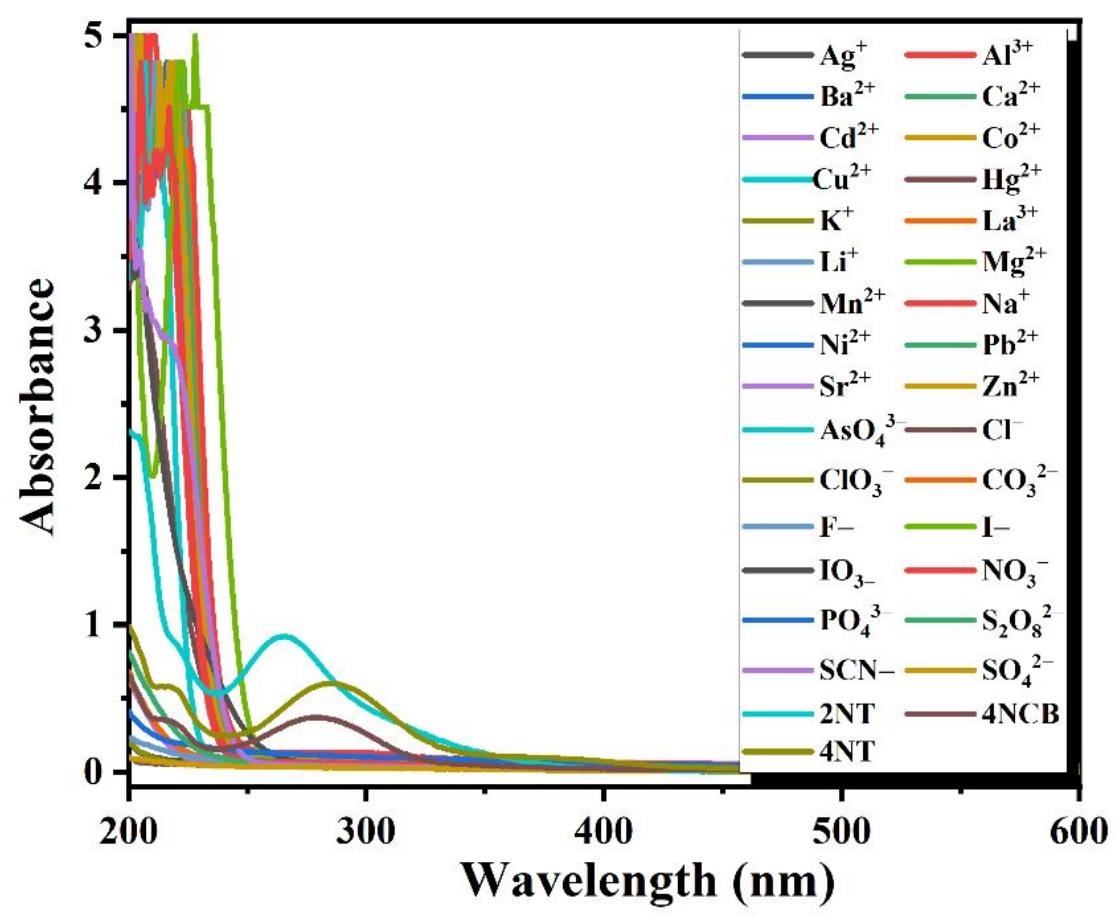

180

181 Figure S21. The UV-Vis spectra of other metal cations, inorganic anions and nitro182 compound. 


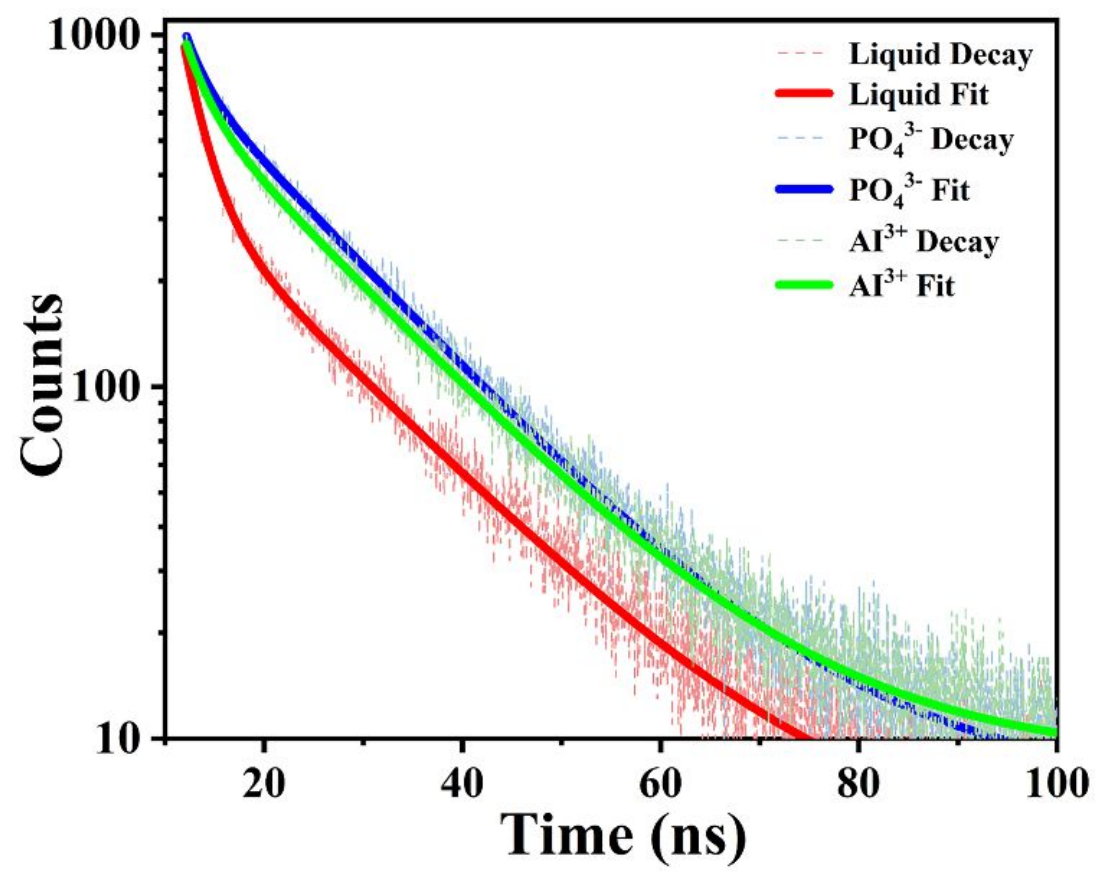

183

184 Figure S22. Changes in lifetimes before and after detection of $\mathrm{Al}^{3+}$ and $\mathrm{PO}_{4}{ }^{3-}$ by 3 . 


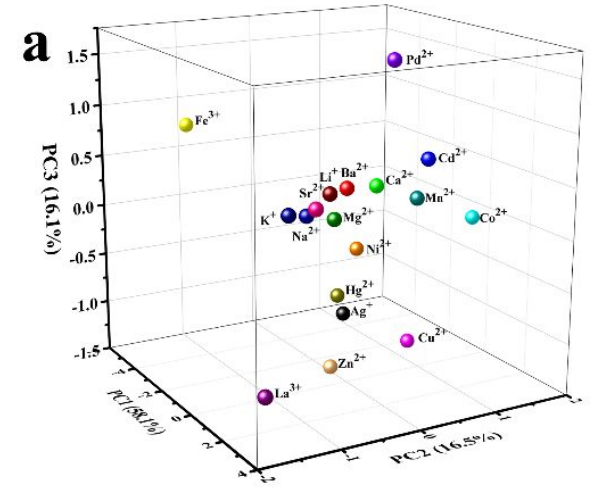

b

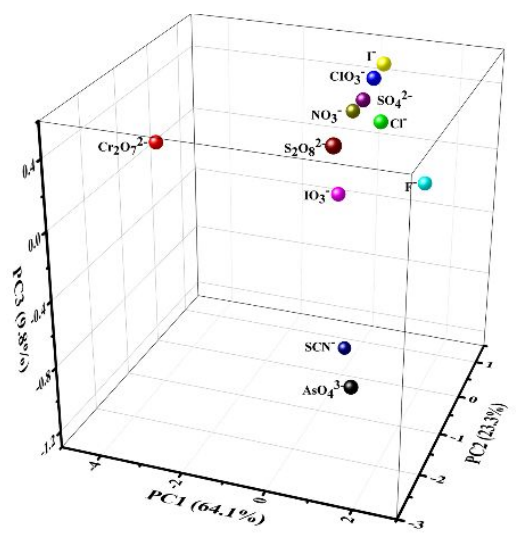

c

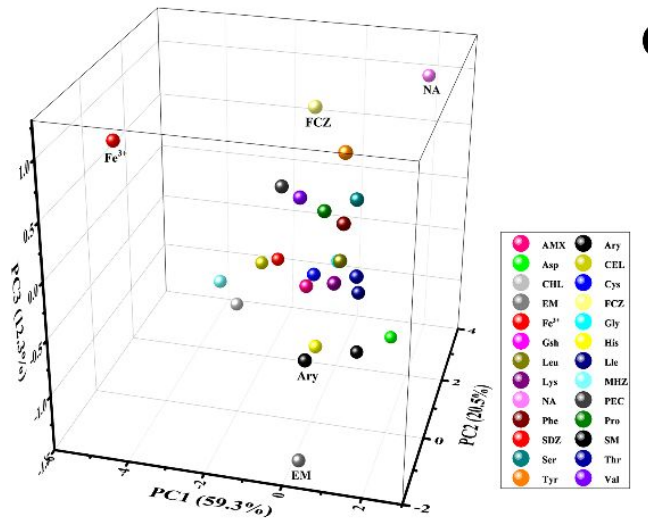

d

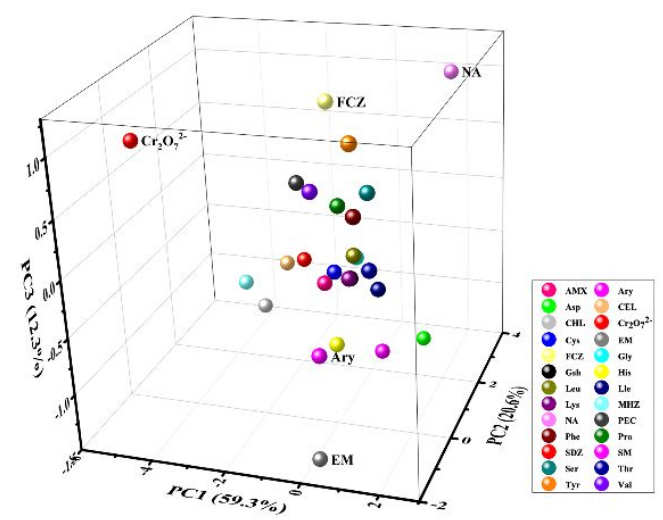

186

Figure S23. 3D PCA plot for the discrimination of (a) inorganic cations, (b) inorganic anions, (c) $\mathrm{Fe}^{3+}$ with organics and (d) $\mathrm{Cr}_{2} \mathrm{O}_{7}{ }^{2-}$ with organics using 1-4.

a

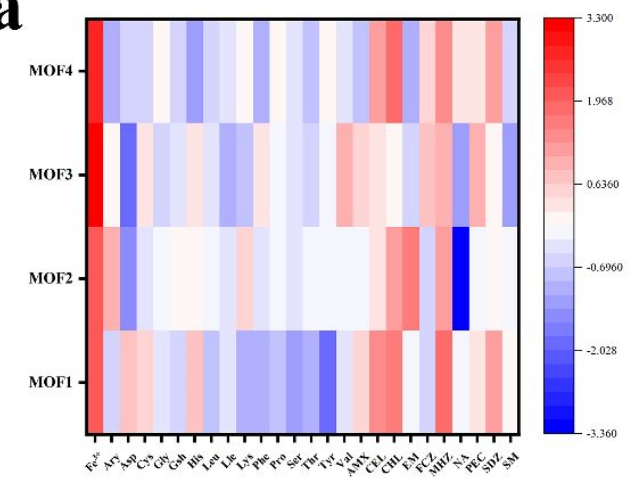

b

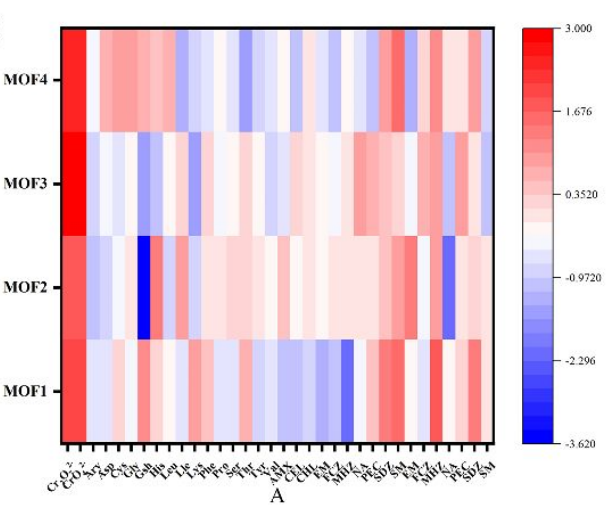

191

192

193 194

Figure 24. $1-F / F_{0}$ array patterns of $\mathbf{1}-\mathbf{4}$ for (a) $\mathrm{Fe}^{3+}$ and (b) $\mathrm{Cr}_{2} \mathrm{O}_{7}{ }^{2-}$ with different amino acids and antibiotics at $10^{-2} \mathrm{M}$. 
(1) Blatov, V. A.; Shevchenko, A. P.; Serezhkin, V. N., TOPOS3.2: a new version of the program package for multipurpose crystal-chemical analysis. J. Appl. Crystallogr. 2000, 33, (4), 1193-1193. (2) Pennington, W. T., DIAMOND - Visual Crystal Structure Information System. J. Appl. Crystallogr. 1999, 32, (5), 1028-1029.

(3) Zhu, S.-Y.; Yan, B., A novel covalent post-synthetically modified MOF hybrid as a sensitive and selective fluorescent probe for Al3+ detection in aqueous media. Dalton Trans. 2018, 47, (5), 1674-1681. (4) Chen, W.-M.; Meng, X.-L.; Zhuang, G.-L.; Wang, Z.; Kurmoo, M.; Zhao, Q.-Q.; Wang, X.-P.; Shan, B.; Tung, C.-H.; Sun, D., A superior fluorescent sensor for $\mathrm{Al}^{3+}$ and $\mathrm{UO}_{2}{ }^{2+}$ based on a Co(ii) metalorganic framework with exposed pyrimidyl Lewis base sites. J. Mater. Chem. A. 2017, 5, (25), 1307913085 .

(5) Zhan, Z.; Jia, Y.; Li, D.; Zhang, X.; Hu, M., A water-stable terbium-MOF sensor for the selective, sensitive, and recyclable detection of $\mathrm{Al}^{3+}$ and $\mathrm{CO}_{3}{ }^{2-}$ ions. Dalton Trans. 2019, 48, (40), 15255-15262. (6) Tian, X.-M.; Yao, S.-L.; Qiu, C.-Q.; Zheng, T.-F.; Chen, Y.-Q.; Huang, H.; Chen, J.-L.; Liu, S.-J.; Wen, H.-R., Turn-On Luminescent Sensor toward $\mathrm{Fe}^{3+}, \mathrm{Cr}^{3+}$, and $\mathrm{Al}^{3+}$ Based on a $\mathrm{Co}(\mathrm{II})$ Metal-Organic Framework with Open Functional Sites. Inorg. Chem. 2020, 59, (5), 2803-2810.

(7) Li, X.; Liu, P.; Niu, X.; Ye, K.; Ni, L.; Du, D.; Pan, J.; Lin, Y., Tri-functional Fe-Zr bi-metalorganic frameworks enable high-performance phosphate ion ratiometric fluorescent detection. Nanoscale. 2020, 12, (37), 19383-19389.

214 (8) Zhan, Z.; Liang, X.; Zhang, X.; Jia, Y.; Hu, M., A water-stable europium-MOF as a multifunctional luminescent sensor for some trivalent metal ions $\left(\mathrm{Fe}^{3+}, \mathrm{Cr}^{3+}, \mathrm{Al}^{3+}\right), \mathrm{PO}_{4}{ }^{3-}$ ions, and nitroaromatic explosives. Dalton Trans. 2019, 48, (5), 1786-1794.

(9) Liu, C.-H.; Guan, Q.-L.; Yang, X.-D.; Bai, F.-Y.; Sun, L.-X.; Xing, Y.-H., Polyiodine-Modified 1,3,5-Benzenetricarboxylic Acid Framework Zn(II)/Cd(II) Complexes as Highly Selective Fluorescence Sensors for Thiamine Hydrochloride, NACs, and $\mathrm{Fe}^{3+} / \mathrm{Zn}^{2+}$. Inorg. Chem. 2020, 59, (12), 8081-8098. (10) Wang, B.; Yang, Q.; Guo, C.; Sun, Y.; Xie, L.-H.; Li, J.-R., Stable Zr(IV)-Based Metal-Organic Frameworks with Predesigned Functionalized Ligands for Highly Selective Detection of Fe(III) Ions in Water. ACS Appl. Mater. Interfaces. 2017, 9, (11), 10286-10295. (11) A Water-Stable Terbium(III)-Organic Framework as a Chemosensor for Inorganic Ions, NitroContaining Compounds and Antibiotics in Aqueous Solutions. Chem.-Asian J. 2019, 14.

(12) Xiao, Q.-Q.; Dong, G.-Y.; Li, Y.-H.; Cui, G.-H., Cobalt(II)-Based 3D Coordination Polymer with Unusual 4,4,4-Connected Topology as a Dual-Responsive Fluorescent Chemosensor for Acetylacetone and $\mathrm{Cr}_{2} \mathrm{O}_{7}{ }^{2-}$. Inorg. Chem. 2019, 58, (23), 15696-15699. dots/ZIF-8 composite and its applications as a fluorescent probe for sensing $\mathrm{Co}^{2+}$ and dichromate. J. Solid State Chem. 2018, 264, 35-41.

231 (14) He, T.; Zhang, Y.-Z.; Kong, X.-J.; Yu, J.; Lv, X.-L.; Wu, Y.; Guo, Z.-J.; Li, J.-R., Zr(IV)-Based 
Metal-Organic Framework with T-Shaped Ligand: Unique Structure, High Stability, Selective Detection, and Rapid Adsorption of $\mathrm{Cr}_{2} \mathrm{O}_{7}^{2-}$ in Water. ACS Appl. Mater. Interfaces. 2018, 10, (19), 16650-16659.

234 (15) Lv, R.; Wang, J.; Zhang, Y.; Li, H.; Yang, L.; Liao, S.; Gu, W.; Liu, X., An amino-decorated dual235 functional metal-organic framework for highly selective sensing of $\mathrm{Cr}(\mathrm{iii})$ and $\mathrm{Cr}(\mathrm{vi})$ ions and detection 236 of nitroaromatic explosives. J. Mater. Chem. A. 2016, 4, (40), 15494-15500.

237 (16) Zhou, Y.; Yang, Q.; Zhang, D.; Gan, N.; Li, Q.; Cuan, J., Detection and removal of antibiotic 238 tetracycline in water with a highly stable luminescent MOF. Sens. Actuators B Chem. 2018, 262, 137239143

240 (17) Li, C.; Zhu, L.; Yang, W.; He, X.; Zhao, S.; Zhang, X.; Tang, W.; Wang, J.; Yue, T.; Li, Z., Amino241 Functionalized Al-MOF for Fluorescent Detection of Tetracyclines in Milk. J. Agric. Food Chem. 2019, $24267,(4), 1277-1283$.

243 (18) Khataee, A.; Jalili, R.; Dastborhan, M.; Karimi, A.; Ebadi Fard Azar, A., Ratiometric visual 244 detection of tetracycline residues in milk by framework-enhanced fluorescence of gold and copper 245 nanoclusters. Spectroc. Acta Pt. A-Molec. Biomolec. Spectr. 2020, 242, 118715.

246 (19) Sun, X.-Y.; Zhang, X.-D.; Xu, Z.-H.; Zhao, Y.; Wang, Z.-L.; Sun, W.-Y., A new two-fold 247 interpenetrated $\mathrm{Cd}(\mathrm{II})$-based metal-organic framework as a fluorescent probe for nitro-aromatic 248 compounds. J. Coord. Chem. 2020, 1-12.

249 (20) Zhang, Y.-Q.; Blatov, V. A.; Zheng, T.-R.; Yang, C.-H.; Qian, L.-L.; Li, K.; Li, B.-L.; Wu, B., A 250 luminescent zinc(ii) coordination polymer with unusual $(3,4,4)$-coordinated self-catenated 3D network 251 for selective detection of nitroaromatics and ferric and chromate ions: a versatile luminescent sensor. 252 Dalton Trans. 2018, 47, (17), 6189-6198. 